\title{
Uptake and Use Efficiencies of Nutrients by Sesame and Bambara Nut Alley Crops as Influenced by Manuring in a Cashew-Based Intercropping System in the Guinea Savanna Agroecology of Nigeria
}

\author{
Samuel Agele1 ${ }^{*}$, Nduka Beatrice², Famuwagun Babadele1, Adejoro Solomon1 \\ ${ }^{1}$ Department of Crop, Soil \& Pest Management, Federal University of Technology, Akure, Nigeria \\ ${ }^{2}$ Cocoa Research Institute of Nigeria, Ibadan, Nigeria \\ Email: ^ohiagele@yahoo.com, soagele@futa.edu.ng
}

How to cite this paper: Agele, S., Beatrice, N., Babadele, F. and Solomon, A. (2018) Uptake and Use Efficiencies of Nutrients by Sesame and Bambara Nut Alley Crops as Influenced by Manuring in a Cashew-Based Intercropping System in the Guinea Savanna Agroecology of Nigeria. Journal of Agricultural Chemistry and Environment, 7, 153-175

https://doi.org/10.4236/jacen.2018.74014

Received: July 23, 2018

Accepted: November 16, 2018

Published: November 19, 2018

Copyright (c) 2018 by authors and Scientific Research Publishing Inc. This work is licensed under the Creative Commons Attribution International License (CC BY 4.0).

http://creativecommons.org/licenses/by/4.0/

\section{(c) (i) Open Access}

\begin{abstract}
Field experiments were conducted at the experimental farm Cocoa Research Institute of Nigeria (CRIN) Sub-Station, Ochaja, in the Southern Guinea Savannaagro ecological zone of Nigeria to examine uptake and use efficiencies of nutrients by Sesame and Bambara nut alley crops as influenced by manuring in a Cashew-based intercropping system. Experimental treatments were based on responses of sole and intercrop mixtures of Sesame and Bambara nut alley crops to Cocoa Pod Husk (CPH), pelletized organic fertilizer and NPK fertilizer in a cashew-based intercropping system. Data were collected on the growth and yield variables of the alley crops. Highest nitrogen harvest index (NHI) for seed and leaf of alley crops were obtained from un-manure treated plants. Cocoa pod husk $(\mathrm{CPH})$ significantly enhanced $\mathrm{P}$ uptake compared with other fertilizers applied. $\mathrm{CPH}$ improved $\mathrm{Na}, \mathrm{Ca}, \mathrm{Mg} \mathrm{Zn}, \mathrm{Cu}, \mathrm{P}, \mathrm{K}$ and carbohydrate in the leaves and $\mathrm{Ca}, \mathrm{Mg}, \mathrm{Zn}, \mathrm{Fe}, \mathrm{Cu}$, crude fibre and carbohydrate contents of seeds of sole crops while Sesame + Bambara had enhanced contents of $\mathrm{N}, \mathrm{Ca}, \mathrm{Mg}, \mathrm{Zn}, \mathrm{Cu}, \mathrm{P}, \mathrm{N}, \mathrm{K}$, moisture, protein, and crude fibre, crude protein, moisture content in leaves. The effects of NPK were significant for $\mathrm{N}, \mathrm{K} \mathrm{Ca}, \mathrm{Zn}, \mathrm{Fe}, \mathrm{Cu}, \mathrm{P}$, moisture and crude fibre, while in the un-manure (control) plots influenced $\mathrm{N}$, fat and protein and nitrogen harvest index (NHI) of leaf and seeds. CPH and NPK fertilizers enhanced nutrient uptake and nitrogen harvest index of alley crops. Nutrient uptake was similar for the varieties of Sesame and Bambara nut as affected by the application of 4.84 and $9.68 \mathrm{Kg}$ pelletized organic fertilizer. Sole Bambara had higher N and
\end{abstract}


$\mathrm{K}$ concentration in leaves compared with Bambara +Sesame. In addition, sole Bambara had higher values of Physiology efficiency (PE), and fertilizer use efficiency (FAE) compared to the mixed crops of Bambara + sesame. However, physiology efficiency (PE), and fertilizer use efficiency (FAE) were significantly lower for Bambara + Sesame. The un-manure plants had enhanced $\mathrm{N}$, $\mathrm{P}$ and $\mathrm{K}$ uptake. Varietal effects were pronounced for most of the resource use efficiency variables measured. The alley crop varieties responded differently to 4.84 and $9.68 \mathrm{~kg}$ pelletized fertilizer treatments (Agronomy Efficiency (AE), N-removed at harvest and Internal Utilization Efficiency (IE) and partial factor productivity (PFP)). Sesame variety NCRIBen04E had enhanced AE, N-remove at harvest, IE and PFP while variety E8 had significantly higher apparent Recovery Efficiency (RE), apparent Recovery Efficiency by difference (RE\%), Physiology Efficiency (PE), Utilization Efficiency (UE), and internal Utilization Efficient (IE). Bambara variety TVSu999 had higher IUE, Agronomy Efficiency (AE), Apparent Recovery Efficiency (RE), Physiology Efficiency (PE) and Fertilizer Agronomy using Efficiency respectively (FAE) compared to variety TVSu1166. The fertilizers affected most of the indicators of nutrient use efficiency (NUE) measured. The effects were significant on AE, agronomic N-use efficiency (ANUE), RE, UE and PFP. NPK fertilizer enhanced Physiology efficiency (PE) and Partial factor production. NPK fertilizer significantly enhanced NUE parameters compared to CPH and un-manure. $\mathrm{CPH}$ manure significantly influenced $\mathrm{RE} \%, \mathrm{PE}$ and IE. The Internal Utilization Efficiency and N-remove at harvest were compared with the un-manure plants (control). The effects of $9.68 \mathrm{~kg} / \mathrm{plot}$ pelletized fertilizer, were pronounced on Agronomy Efficiency (AE), Apparent Recovery Efficiency by difference (RE\%), Physiology Efficiency (PE), Utilization Efficiency (UE), $\mathrm{N}$-removed at harvest and Internal Utilization Efficiency (IE). Similar trends were observed in the responses NUE of Sesame and Bambara manuring. The responses sole crops in terms of RE, PE UE PFP were similar while their intercrop combinations had significantly higher AE, RE, UE, PFP and N removed at harvest. Sole Sesame significantly influence Agronomy Efficiency (AE), Utilization Efficiency (UE), Internal Efficiency (IE) and Partial Fertilizer Production (PFP) and sole Bambara under NPK fertilizer had enhanced N-removed at harvest and apparent recovery by difference (RE\%). Bambara + Sesame under cocoa pod husk $(\mathrm{CPH})$ manure had enhanced apparent recovery efficiency by difference (RE\%), fertilizer use efficiency (FAE) and internal utilization efficiency (IE). Sesame variety NCRIBen04E had enhanced Agronomy Efficiency (AE), N-removed at harvest and Internal Utilization Efficiency (IE) under 9.68 $\mathrm{kg}$ treatment while variety E8 had higher partial factor productivity (PFP) at $4.84 \mathrm{~kg} /$ plot pelletized organic fertilizer.

\section{Keywords}

Tropics, Fruit Tree-Based Agroforestry, Resources Use, Mixture Productivity, Agriculture, Food Security 


\section{Introduction}

In recent years, the increased tendency for intensive vegetable production in the tropics has increased the demand for high application rates of fertilizers to maximize yields. High costs and accessibility of fertilizer constitute huge constraints to the success of intensive vegetable production [1] [2]. The continuous cropping systems of the tropics reduce soil fertility. Rapid degradation of soil quality and accelerated erosion in sub-Saharan Africa has become a huge problem where annual $\mathrm{N}$ depletion rate is about $26 \mathrm{~kg} \mathrm{year}^{-1}$ [3] [4]. Increase in $\mathrm{N}$ uptake and utilization efficiency by crops without deleterious effect on yield and ecosystem are required [2] [5].

Worldwide, the interest in the use of organic materials as sources of nutrients (fertilizers) for the production of organically grown vegetables had increased [5]. A balanced use of organic and mineral fertilizer could enhance stable soil chemical, physical and biological properties in addition to a large and rapid rate of nutrient turn over and high soil fertility status within the soil-plant system. Bair [6] opined that proper soil fertility management and sustainable agriculture can be achieved with the use of both mineral fertilizer and organic manure. Paul and Mannan [7] suggested that integrated nutrient management through combined use of organic wastes and chemical fertilizers can be an effective approach to combat nutrient depletion and promote sustainable crop productivity. Increases in soil organic matter pool have the potential to increase crop yield and $\mathrm{N}$ uptake. Replenishing the nutrients removed by crops by recycling back of agricultural wastes into the soil can sustain soil and crop productivity [7]. There is ample opportunity for nutrient recycling in the tropics where huge amounts of agricultural wastes are generated yearly. It would be necessary to develop economically and environmentally suitable integrated nutrient management packages for sustaining the changing needs of intensive vegetable production in the tropics. Integrated use of organic wastes and mineral fertilizer is reported to reduce the cost and amount of fertilizer required by crops. This practice is also known to improve nutrient use efficiency and chemical and nutritional quality of crops [8]. Renewable management of organic sources of $\mathrm{N}$ through use of agricultural waste materials would improve the quality of the environment and soil health.

The growth and yield performance of a crop are a function of the status of soil nutrients (especially $\mathrm{N}$ ) [9]. Yield increase may respond to additional $\mathrm{N}$ supply and increased $\mathrm{N}$ utilisation efficiency for yield production. Physical and chemical availability of nutrients and plant physiological factors affect the rate of nutrient absorption in plants [5]. Potential availability of nutrients for plant uptake is a function of its solubility in the growing media and its physical location in the root zone. Physiological factors affect diffusion transport and rates of nutrient transfer across root boundaries and nutrient uptake through differentiation between the absorption of water and nitrates [8]. The level of $\mathrm{N}$ supply to the growing tissues, flowering and fruit set and $\mathrm{N}$ accumulation/concentration in 
plant tissues (fruits) are affected by the time of $\mathrm{N}$ application and root absorption efficiency. Although a high level of $\mathrm{N}$ supply to the growing tissues will be maintained when the time of $\mathrm{N}$ application coincides with maximum root absorption efficiency, maximum partitioning of $\mathrm{N}$ between the reproductive and vegetative organs may not be attained [5] [8].

Most crops are capable of accumulating huge amounts of nitrates $\left(\mathrm{NO}_{3}\right)$ in their tissues [10]. Although nitrate nitrogen $\left(\mathrm{NO}_{3}-\mathrm{N}\right)$ contents in plant parts are important to its quality, a high nitrate concentration in edible plant parts is detrimental to human health [2]. Causal relations between nitrate intake and methaemoglobinaemia and carcinogenic nitrosamines have been established. Variability in the efficiency of $\mathrm{N}$ translocation and nitrogen harvest index (NHI) by nitrogen availability were confirmed for lettuce leaf [11] and tomato [2]. Soil mal-nutrition is becoming widespread and increasing problems especially in the tropics hence the need to increase through management practices, the $\mathrm{N}$ uptake and utilisation efficiencies of crops. Accumulation and partitioning of biomass and $\mathrm{N}$ between vegetative and reproductive components (NHI) are commonly used in addition to other criteria in the selection for yield in crops [5] and to create cultivars adapted to low input management systems. Although these attributes vary in diverse ecologies, there are however, scanty information on uptake and use of soil $\mathrm{N}$ in crop species common to the cropping systems of the humid tropics [5] [12].

Our working hypotheses were based on literature reports. Rather et al. [9] and Graham [13] postulated that $\mathrm{N}$ efficiency in terms of high yield production is affected by the status of soil $\mathrm{N}$, and crop varieties may differ in performance under varying soil $\mathrm{N}$ status. Rather et al. [9] and Agele et al. [8] opined that crop yield responses may increase under fertilizer treatments possibly due to improved efficiency of nutrient utilization for yield production. The nutrient release characteristics of organic materials depends on the material, particle size, soil temperature and moisture content [8]. In addition to this, the availability of soil $\mathrm{N}$, the efficiency of its uptake and use in biomass and fruit production are also affected by crop types, soil and climatological characteristics of a region [8] [14] [15]. Based on these reports, some hypotheses were formulated as follows: That externally applied nutrients from different sources (organic and inorganic) would results in partitioning of large amounts of nutrients for growth. The efficiencies of nitrogen uptake and utilization for yield production and hence NHI are strongly affected by nutrient availability from fertilizer sources. The objectives of this study were to provide information which would improve understanding of the nutrient cycling of incorporated agricultural wastes used alone, and in combination with reduced rates of chemical fertilizer and to develop an integrated nutrient management package for vegetable production in the tropics.

\section{Materials and Methods}

Experiments were conducted between 2013 and 2015 cropping seasons at the experimental farm Cocoa research institute of Nigeria Sub-Station located in 
Ochaja, Kogi State in the Southern Guinea Savanna agroecological zone of Nigeria. The objective was to address the constraints of declining soil fertility via manuring to enhance uptake and use efficiencies of nutrients and hence optimizing the benefits of resource availability within cashew alley. Experimental treatments were based on responses of sole and intercrop mixtures of Sesame and Bambara nut alley crops to Cocoa Pod Husk $(\mathrm{CPH})$, pelletized organic fertilizer and NPK fertilizer in a cashew-based intercropping system. Treatments were a factorial scheme consisting of crop types (sole and intercrop mixtures of Sesame and Bambara nut) and fertilizers (Cocoa Pod Husk (CPH)), pelletized organic manure and NPK fertilizer arranged using RCBD at three replications. There was an unmanured control. The fertilizers were applied two weeks after planting (WAP). Data were collected on the growth and yield variables of the alley crops. Bambara nut and Sesame seeds were planted in the Cashew alley and separated by unplanted cashew boarder plant. Fertilizers were applied two weeks after planting (WAP) using Cocoa Pod Husk (CPH: $6.17 \mathrm{~kg} / \mathrm{plot}$ ) and N.P.K $(1.44 \mathrm{~kg} / \mathrm{plot})$ in a twelve treatments layout comprised of sole and intercrop combination of Sesame and Bambara nut as alley crops in cashew. In addition, the responses of varieties of Bambara nut (TVSu1166 and TVSu999) and Sesame (E-8 and NCRIBen04E (Ex-Sudan)) to varying rates (0, 4.84 and $9.68 \mathrm{~kg} / \mathrm{plot})$ of organic pelletized manure in cashew alley was examined.

Data were collected on nutrient uptake and use efficiencies using indicators such as Agronomic Efficiency (AE), Physiological Efficiency (PE), Apparent Recovery (RE), Apparent Recovery Efficiency by difference (RE\%), Utilization Efficiency (UE), Internal Utilization Efficiency (IE), Partial Factor Production (PFP). Agronomic Efficiency (AE): AE is calculated in units of yield increase per unit of nutrient applied. Its more closely reflects the direct production impact of an applied fertilizer and relates directly to economic return. The calculation of $\mathrm{AE}$ requires knowledge of yield without nutrient input, so is only known when research plots with zero nutrient input have been implemented on the farm [16]:

$$
\text { Agronomy efficiency }(\mathrm{AE})=\frac{\mathrm{Y}-\mathrm{Yo}}{\mathrm{F}}
$$

where $\mathrm{Y}=$ Crop yield with fertilizer, Yo = Crop yield without fertilizer, $\mathrm{F}=$ Amount of fertilizer applied. Agronomic Nutrient use efficiency (ANUE): This is defined as the ratio of grain yield with $\mathrm{N}$ application minus grain yield without $\mathrm{N}$ application. This was used to describe the capability of yield increase per kilogram pure $\mathrm{N}$ (kg of crop yield increase per $\mathrm{kg}$ of nutrient applied):

$$
\text { Agronomic Nutrient Use Efficiency }(\text { ANUE })=\frac{Y n-Y o}{F n}
$$

where AE is agronomic efficiency, Yn and Yo are crop yields $\left(\mathrm{kg} \cdot \mathrm{ha}^{-1}\right)$ with and without the nutrient being tested, Fn is the amount of nutrient applied $\left(\mathrm{kg}^{\mathrm{h}} \mathrm{ha}^{-1}\right)$.

Physiological efficiency was calculated as yield increased per $\mathrm{kg}$ increased in Nutrient taken up and express as:

$$
\text { Competitive Ratio }(\mathrm{CRb})=\frac{\mathrm{Yab}}{\mathrm{Yaa}} \div \frac{\mathrm{Yba}}{\mathrm{Ybb}} \times \frac{\mathrm{Zab}}{\mathrm{Zba}}
$$


CRb: Competative ratio of Bambara nut with respect to sesame, Yab: Nutrient uptake by Bambara nut in intercropping, Yaa: Nutrient uptake by Bambara nut in sole crop, Yba: Nutrient uptake by Sesame in intercropping, Ybb: Nutrient uptake by Sesame in sole crop, Zab: Nutrient uptake by Bambara nut in intercropping, Zba: Nutrient uptake by Bambara nut in intercropping.

Physiological $\mathrm{N}$ use efficiency (PNUE): PNUE is defined as the yield increase in relation to the increase in crop uptake of the nutrient in above-ground parts of the plant. Like AE and RE, it needs a plot without application of the nutrient of interest to be implemented on the site. It also requires measurement of nutrient concentrations in the crop and is mainly measured and used in research. Or defined as the ratio of yield increased with $\mathrm{N}$ application and it reflected the use efficiency of $\mathrm{N}$ absorbed ( $\mathrm{kg}$ yield increase per $\mathrm{kg}$ of increase in nutrient taken up):

Physiological $\mathrm{N}$ use efficiency $(\mathrm{PNUE})=(\mathrm{kg}$ yield increase $) /(\mathrm{kg}$ fertilizer nutrient uptake) :

$$
\mathrm{PNUE}=\frac{\mathrm{Y}-\mathrm{Yo}}{\mathrm{U}-\mathrm{Uo}}
$$

where PE: Physiological efficiency, Y: Crop yield with applied nutrient, Yo: Crop yield with no applied nutrient, U: Plant nutrient uptake of above ground biomass at maturity, Uo: Plant uptake with zero fertilizer.

Apparent recovery or apparent efficiency (RE): RE (kg of nutrient uptake by the $\mathrm{c} \mathrm{kg}$ of nutrient applied); is one of the more complex forms of NUE expressions and is most commonly defined as the difference in nutrient uptake in above-ground parts of the plant between the fertilized and unfertilized crop relative to the quantity of nutrient applied. It is often the preferred NUE expression by scientists studying the nutrient response of the crop. Like AE, it can only be measured when a plot without nutrient has been implemented on the site, but in addition requires measurement of nutrient concentrations in the crop.

$$
\text { Apparent Recovery Efficiency }(\mathrm{ARE})=\frac{\mathrm{Nn}-\mathrm{No}}{\mathrm{Fn}} \times 100
$$

where: RE is apparent recovery efficiency, Nn and No $\left(\mathrm{kg} \cdot \mathrm{ha}^{-1}\right)$ are nutrient uptake by the crop with and without the applied nutrient respectively, and Fn $\left(\mathrm{kg} \cdot \mathrm{ha}^{-1}\right)$ is the amount of nutrient applied. Apparent recovery efficiency by difference was computed according to [17].

$$
\text { Apparent recovery efficiency by difference } \mathrm{RE}=\frac{\mathrm{U}-\mathrm{Uo}}{\mathrm{F}}
$$

where: $\mathrm{U}$ is Total nutrient uptake in above ground crop biomass with nutrient applied, Uo is Nutrient uptake in above ground crop biomass with no nutrient applied, $\mathrm{F}=$ Amount of fertilizer applied.

Utilization efficiency (UE): Nutrient Utilization efficiency is a product of physiological and apparent recovery efficiency. It can be calculated according to [18] (Dobermann (2007)). 


\section{Utilization Efficiency $\mathrm{UE}\left(\mathrm{mg} \cdot \mathrm{mg}^{-1}\right)=\mathrm{PE} \times \mathrm{ARE}$}

Internal Utilization efficiency (IE): IE is defined as the yield in relation to total nutrient uptake. It varies with genotype, environment and management. A very high IE suggests deficiency of that nutrient. Low IE suggests poor internal nutrient conversion due to other stresses (deficiencies of other nutrients, drought stress, heat stress, mineral toxicities, pests etc.).

$$
\text { Internal Utilization efficiency } \mathrm{IE}=\frac{\mathrm{Y}}{\mathrm{U}}
$$

where: $\mathrm{Y}=$ Yield of harvested portion of crop with nutrient applied, $\mathrm{U}=$ Total nutrient uptake in above ground crop biomass with nutrient applied.

Partial Factor Productivity (PFP): PFP is a simple production efficiency expression, calculated in units of crop yield per unit of nutrient applied using the method of [19].

$$
\text { Partial Factor Productivity } P F p=\frac{Y}{F}
$$

where: $\mathrm{Y}=$ Yield of harvested portion of crop with nutrient applied, $\mathrm{F}=$ Amount of nutrient applied.

Data on determination of crop mixture productivity between Bambara and Sesame

System productivity index (SPI) was calculated according to [19]:

$$
\mathrm{SPI}=(\mathrm{Sa} / \mathrm{Sb}) \mathrm{Yb}+\mathrm{Ya}
$$

where $S$ is the mean yield of each plant in sole culture and $\mathrm{Y}$ is the mean yield of each plant in mixed crop.

Relative yield was computed using the formula as described by [20]:

$$
\mathrm{RY}=\frac{\mathrm{YA}}{\mathrm{SA}}=\frac{\text { Individual component crop yield in mixture }(\mathrm{YA})}{\text { Individual component crop yeild in sole crop }(\mathrm{SA})}
$$

Relative yield total (RYT): Relative yield total is defined as the sum of relative yields of the species in mixture expressed as a ratio of its yield in monoculture. Mathematically, as described by [21], it is expressed as:

$$
\mathrm{RYT}=\mathrm{ry}_{\mathrm{a}}+\mathrm{ry}_{\mathrm{b}}+\cdots \mathrm{r}+\mathrm{y}_{\mathrm{n}}
$$

where: $r y_{a}$ and $r y_{b}$ are the relative yields of species a and b respectively.

Nutrient use efficiency (NUE) is expressed in several ways as reported in literature as follows.

The efficiency of conversion of nutrient taken up by the plant into crop biomass was calculated as follows;

$$
\text { Conversion efficiency of nutrient } \mathrm{X}=\frac{\text { Total above ground biomass }}{\text { Total uptake of nutrient }}
$$

where: Total aboveground biomass is the sum of seed + leaves biomass expressed on a dry weight basis. Uptake efficiency refers to the ability of crop to extract or absorb nutrients from the soil. The uptake of nutrients was calculated from the measurement of N. P and K content in the seeds and leaves biomass (Root were not considered). Nutrient accumulated (Uptake). Total plant uptake $=\mathrm{N}$ concentration in the sample biomass multiply by weight of the biomass. 
The uptake of nutrients was calculated from the measurements of $\mathrm{N}, \mathrm{P}$, and $\mathrm{K}$ contains in seed and leaves biomass (root were not considered in this experiment).

$$
\begin{aligned}
& \text { Uptake efficiency } \\
& =\frac{\text { Total above }- \text { ground nutrient in the plant at maturity }(\mathrm{Nt})}{\text { Nutrient supplied }(\mathrm{Ns})}
\end{aligned}
$$

The conversion efficiencies for $\mathrm{N}, \mathrm{P}$, and $\mathrm{K}$ have the unit of $\mathrm{Kg} \mathrm{DM} \mathrm{Kg} \mathrm{N}{ }^{-1}$, $\mathrm{Kg}$ DM Kg P ${ }^{-1}$, Kg DM Kg K ${ }^{-1}$.

Nitrogen Harvest index (NHI): $\mathrm{N}$ harvest index was defined as the percent of grain $\mathrm{N}$ uptake to total plant $\mathrm{N}$ uptake. The proportion of total plant $\mathrm{N}$ partitioned to the seed is called the $\mathrm{N}$ harvest index (NHI) according to [22]:

$$
\begin{gathered}
\mathrm{N} \text { harvest index }(\mathrm{NHI})=\frac{\text { Seed } \mathrm{N} \text { uptake }}{\text { total plant } \mathrm{N} \text { uptake }} \\
\mathrm{NUPE}=(\mathrm{kg} \text { nutrient taken up }) /(\mathrm{kg} \text { nutrient available }) \\
\mathrm{NUPE}=\frac{\mathrm{U}}{\mathrm{F}+\mathrm{S}}
\end{gathered}
$$

where: N: Nutrient, U: Plant nutrient uptake of above ground biomass at maturity, F: Fertilizer applied, S: Nutrient in the soil.

Nitrogen Use Efficiency (NUE): This is a term used to indicate the ratio between the amount of fertilizer $\mathrm{N}$ removed from the field by the crop and the amount of fertilizer $\mathrm{N}$ applied. This ratio describes the efficiency of $\mathrm{N}$ fertilizer utilization in crop production express in \% according to the methods of [23]:

$$
=\frac{\mathrm{N} \text { remove with harvest }}{\mathrm{N} \text { fertilizer }(\text { Minerial } \mathrm{N})} \times 100
$$

Fertilizer use efficiency reflects the recovery of applied fertilizer by the crop, however from the crop perspective, $\mathrm{N}$ (or other nutrient) use efficiency is a measure of biomass produced as a function of the $\mathrm{N}$ (or other nutrient) available to that crop.

Fertilizer agronomic efficiency refers to the quantity of yields obtained from the application of $1 \mathrm{Kg}$ of fertilizer. It can be calculated as $\mathrm{Kg}$ of fertilizer or an element of interest (For example N, P, K etc.) and calculated using the procedure as outlined as follows:

$$
\left(\mathrm{AEF} ; \mathrm{kg} \cdot \mathrm{kg}^{-1}\right)=(\text { yield at } \mathrm{Fx}-\text { yield at F0) to (applied F at Fx). }
$$

where $\mathrm{F}$ is fertilizer, Yields at $\mathrm{Fx}$ is the yield obtained from the amount of fertilizer applied, and Yield at Fo is the yield from the control.

\section{Results and Discussion}

The results of the pre-cropping soil properties are presented in Table 1. The applied fertilizers ( $\mathrm{CPH}, \mathrm{NPK}$ and Pelletized organic fertilizer) improved soil physical and chemical properties (Table 2(a) and Table 2(b)). Soil pH under the 
Table 1. Pre-cropping physical and chemical propertiesof soil of site of study.

\begin{tabular}{|c|c|c|}
\hline Soil properties & Experiment 1 (2013) & Experiment 2 (2014) \\
\hline \multicolumn{3}{|l|}{ Chemical properties } \\
\hline $\mathrm{pH}\left(\mathrm{H}_{2} \mathrm{O}\right) 1: 1$ & 6.70 & 6.35 \\
\hline Organic carbon $(\mathrm{g} / \mathrm{kg})$ & 0.54 & 0.92 \\
\hline Organic matter $(\mathrm{g} / \mathrm{kg})$ & 0.92 & 1.59 \\
\hline Nitrogen $(\mathrm{g} / \mathrm{kg})$ & 0.94 & 0.37 \\
\hline Available Phosphorus (g/kg) & 0.50 & 1.82 \\
\hline \multicolumn{3}{|l|}{ Exchangeable bases $\left(\mathrm{cmol} \cdot \mathrm{kg}^{-1}\right)$} \\
\hline $\mathrm{K}$ & 0.54 & 0.01 \\
\hline $\mathrm{Na}$ & 0.33 & 0.01 \\
\hline $\mathrm{Ca}$ & 1.47 & 1.44 \\
\hline $\mathrm{Mg}$ & 0.72 & 0.74 \\
\hline \multicolumn{3}{|l|}{ Exchangeable acidity $\left(\mathrm{cmol} \cdot \mathrm{kg}^{-1}\right)$} \\
\hline Aluminum $\left(\mathrm{Al}^{3+}\right)$ & 0.14 & 0.13 \\
\hline $\mathrm{H}^{+}$ & 0.72 & 0.56 \\
\hline Effective cat ion exchange capacity (ECEC) & 2.77 & 2.81 \\
\hline \multicolumn{3}{|l|}{ Physical properties (\%) } \\
\hline Sand & 84.14 & 73.12 \\
\hline Silk & 5.26 & 5.94 \\
\hline Clay & 10.61 & 15.63 \\
\hline Water holding capacity (WHC)\% & 48.27 & 41.21 \\
\hline Textural class & \multicolumn{2}{|c|}{ Sandy loam } \\
\hline
\end{tabular}

Table 2. (a) Manuring effect on physical and chemical properties of soil in cashew-based Intercropping system; (b) Effects of organic fertilizer (Fert Plus) on physical and chemical properties of soil in cashew-based Intercropping system.

(a)

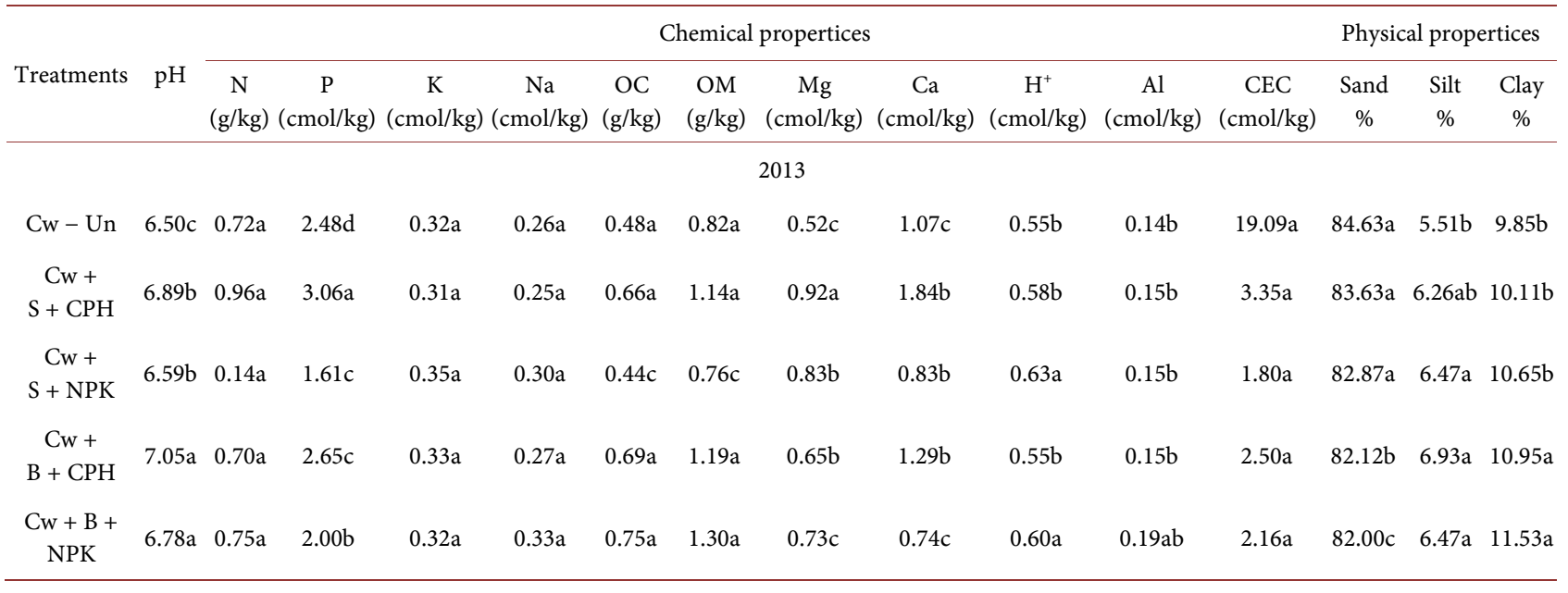




\section{Continued}

\begin{tabular}{|c|c|c|c|c|c|c|c|c|c|c|c|c|c|c|c|}
\hline $\begin{array}{l}\mathrm{Cw}+\mathrm{S}+ \\
\mathrm{B}+\mathrm{CPH}\end{array}$ & $7.05 \mathrm{ab}$ & $0.67 \mathrm{a}$ & $2.84 \mathrm{~b}$ & $0.31 \mathrm{a}$ & $0.26 \mathrm{a}$ & $0.60 \mathrm{a}$ & $1.03 \mathrm{a}$ & $0.50 \mathrm{c}$ & $0.91 \mathrm{~b}$ & $0.74 \mathrm{a}$ & $0.31 \mathrm{a}$ & $1.88 \mathrm{a}$ & $83.13 \mathrm{~b}$ & $6.60 \mathrm{a}$ & $10.27 \mathrm{~b}$ \\
\hline $\begin{array}{l}\mathrm{Cw}+\mathrm{S}+ \\
\mathrm{B}+\mathrm{NPK}\end{array}$ & $6.54 \mathrm{~b}$ & $0.91 \mathrm{a}$ & $2.22 \mathrm{a}$ & $0.35 \mathrm{a}$ & 0.28 & $0.56 \mathrm{~b}$ & $0.96 \mathrm{~b}$ & $0.99 \mathrm{a}$ & $1.03 \mathrm{a}$ & $0.66 \mathrm{a}$ & $0.20 \mathrm{a}$ & $2.57 \mathrm{a}$ & $83.01 \mathrm{a}$ & $5.74 \mathrm{~b}$ & $11.25 \mathrm{a}$ \\
\hline \multicolumn{16}{|c|}{2014} \\
\hline $\begin{array}{l}\mathrm{Cw}+\mathrm{S} \\
+\mathrm{CPH}\end{array}$ & $6.41 \mathrm{ab}$ & $1.04 \mathrm{~b}$ & $1.22 \mathrm{a}$ & $0.37 \mathrm{~b}$ & $0.29 b$ & $0.35 \mathrm{~d}$ & $0.60 \mathrm{~d}$ & $1.41 \mathrm{a}$ & $0.60 \mathrm{a}$ & $0.83 a$ & $0.16 \mathrm{~b}$ & $2.86 a$ & $83.13 \mathrm{a}$ & $4.18 \mathrm{~d}$ & $11.45 \mathrm{~b}$ \\
\hline $\begin{array}{l}\mathrm{CW}+\mathrm{S} \\
+\mathrm{NPK}\end{array}$ & $6.38 \mathrm{ab}$ & $1.07 \mathrm{a}$ & $1.36 \mathrm{a}$ & $0.36 \mathrm{~b}$ & $0.34 \mathrm{ab}$ & $0.64 b$ & $1.11 \mathrm{~b}$ & $1.10 \mathrm{~b}$ & $0.52 b$ & $0.64 b$ & $0.16 \mathrm{~b}$ & $2.25 \mathrm{~b}$ & $82.62 a$ & $5.93 \mathrm{~b}$ & $11.45 b$ \\
\hline $\begin{array}{l}\mathrm{Cw}+\mathrm{B} \\
+\mathrm{NPK}\end{array}$ & $6.24 \mathrm{~b}$ & $0.80 \mathrm{c}$ & $0.98 \mathrm{c}$ & $0.32 \mathrm{c}$ & $0.33 \mathrm{ab}$ & $0.41 \mathrm{c}$ & $0.70 \mathrm{c}$ & $1.22 \mathrm{~b}$ & $0.59 \mathrm{a}$ & $0.73 a$ & $0.22 \mathrm{a}$ & $2.78 \mathrm{a}$ & $82.63 a$ & $5.94 \mathrm{~b}$ & $11.44 \mathrm{~b}$ \\
\hline $\begin{array}{c}\mathrm{Cw}+\mathrm{S} \\
+\mathrm{B}+\mathrm{CPH}\end{array}$ & $6.12 b$ & $1.06 \mathrm{a}$ & $1.11 \mathrm{~b}$ & $0.35 c$ & $0.40 \mathrm{a}$ & $0.50 \mathrm{c}$ & $0.87 \mathrm{c}$ & $0.77 \mathrm{~d}$ & $0.40 \mathrm{~b}$ & $0.48 \mathrm{~d}$ & $0.23 \mathrm{a}$ & $1.84 \mathrm{~d}$ & $79.46 \mathrm{~d}$ & $6.60 \mathrm{~b}$ & $13.94 \mathrm{a}$ \\
\hline $\begin{array}{c}\mathrm{Cw}+\mathrm{S} \\
+\mathrm{B}+\mathrm{NPK}\end{array}$ & $6.60 \mathrm{a}$ & $0.99 \mathrm{~b}$ & $1.18 \mathrm{~b}$ & $0.38 \mathrm{a}$ & $0.36 \mathrm{ab}$ & $0.68 \mathrm{a}$ & $1.18 \mathrm{~b}$ & $0.91 \mathrm{c}$ & $0.45 c$ & $0.62 c$ & $0.15 b$ & $1.96 \mathrm{c}$ & $80.13 b$ & $6.71 \mathrm{a}$ & $13.16 \mathrm{a}$ \\
\hline
\end{tabular}

(b)

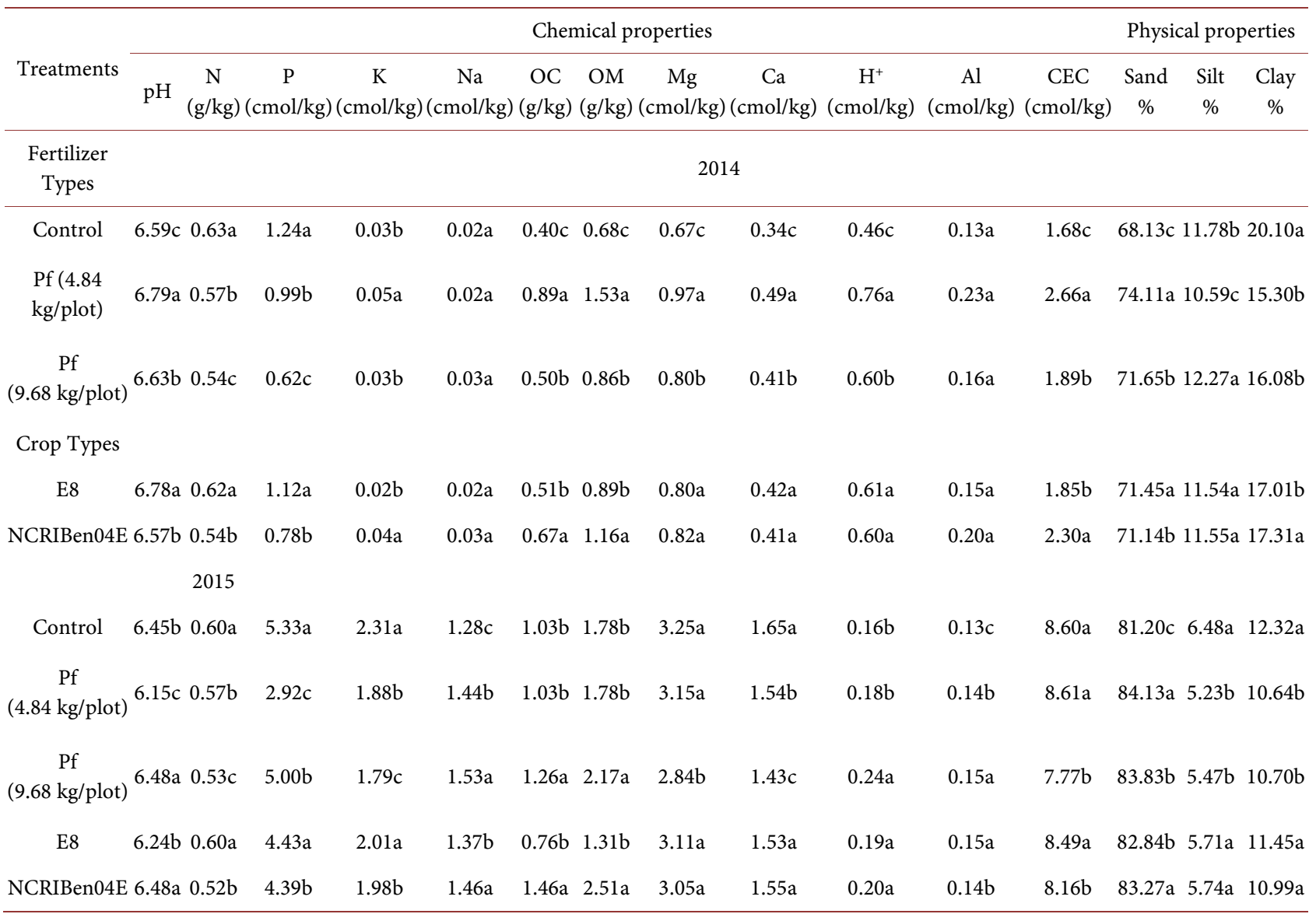


fertilizers was within the satisfactory range for Sesame and Bambara production (5.5 - 7.0). Pelletized fertilizer (4.84 and $9.68 \mathrm{~kg} / \mathrm{plot})$ significantly influenced soil $\mathrm{pH}, \mathrm{OM}, \mathrm{K}, \mathrm{Ca}, \mathrm{Mg}$ and $\mathrm{CEC}$, soil texture and water holding capacity (WHC) silt and clay properties and both rates influenced OM and N. Soil $\mathrm{pH}$ ranged from 5.5 - 7.0 and NPK fertilizer, $\mathrm{CPH}$ and Pelletized organic fertilizer significantly increased the soil organic matter content. Pelletized fertilizer at 4.84 and $9.68 \mathrm{~kg} / \mathrm{plot}$ significantly influenced soil $\mathrm{pH}, \mathrm{OM}, \mathrm{K}, \mathrm{Ca}, \mathrm{Mg}$ and CEC. The applied fertilizers (CPH, NPK and pelletized organic fertilizer) improved physical and chemical properties of the soil. The un-manure (Control) differed significantly from fertilizer treatments for soil $\mathrm{pH}$ and clay contents. Organic carbon obtained increased slightly in the Cocoa pod husk (CPH) and NPK fertilizer treated soils than the un-manure. Soil organic carbon (SOC) can be increased by mixed cropping, or with the use of cover crops. The treatment involving pelletized organic fertilizer had enhanced N, OM content. Organic manures improved the soil properties, thus the use of a leguminous plant (Bambara) not only influenced the nitrogen $(\mathrm{N})$, Potassium $(\mathrm{K})$ and phosphate $(\mathrm{P})$, but also the exchangeable cations and the soil organic carbon (SOC) content.

Uptake of $\mathrm{N}$ and $\mathrm{K}$ for sole sesame was significant under NPK application compared to the organic fertilizers, $\mathrm{P}$ uptake was significantly influenced by application of $\mathrm{CPH}$ manure and enhanced uptake of $\mathrm{N}$ and P for Sesame (Table 3 and Table 4). Un-manured (control) plants had a significantly higher N compared to the fertilizer treated plants. Sole Sesame leaves had significantly higher chemical constituents for NPK, while N harvest index for Sesame + Bambara was significant $\mathrm{CPH}$ manure influenced Nitrogen Harvest index (NHI) compared to NPK and un-manure (Table 2(a) and Table 2(b)). Sesame + Bambara had higher Nitrogen harvest index (NHI) for NPK treatment NPK significantly influenced all the parameters measured except NHI which was significant for un-manure control. Sole Sesame under NPK fertilizer influenced NHI compared with Sesame + Bambara Sole Bambara leaves had higher $\mathrm{N}$ and $\mathrm{K}$ concentration compared to the Bambara + Sesame (Table 3). The Sesame nutrient uptake was similar in both cropping year for both varieties (E8 and NCRIBen04E) under application of $9.68 \mathrm{Kg}$ pelletized fertilizer compared with $4.84 \mathrm{Kg}$ pelletized fertilizer were enhanced for Sesame variety E8. Pelletized fertilizer $(4.84 \mathrm{~kg} / \mathrm{plot})$ promoted uptake of $\mathrm{N}$ significantly compared to un-manure (Table 4). While $9.68 \mathrm{~kg}$ enhanced contents of $\mathrm{P}, \mathrm{K}, \mathrm{N}$ and $\mathrm{K}$. The Sesame variety E8 was better in terms of $\mathrm{N}$ uptake $(\mathrm{P}>0.05)$ compared with NCRIBen04E. Sesame variety E8 had enhanced $\mathrm{N}$ under application of $4.84 \mathrm{~kg}$ pelletized fertilizer compare to 9.68 $\mathrm{kg}$ in both years. The plots for which organic fertilizer at $9.68 \mathrm{~kg}$ was applied had higher uptake of $\mathrm{P}$ and $\mathrm{K}$ compared with un-manure (control) and $4.86 \mathrm{~kg}$ pelletized fertilizer.

Bambara plants had higher leaf $\mathrm{N}$ content in both cropping years, while the NPK fertilizer influenced $\mathrm{P}$ and $\mathrm{K}$ (Table 5 and Table 6). The un-manure had higher $\mathrm{N}$ and $\mathrm{P}$ contents in leaves compared to fertilizers treatment for Sole Bambara. Bambara + Sesame had high $\mathrm{P}$ and $\mathrm{K}$ except for $\mathrm{N}$ contents which was 
Table 3. Manuring effects on chemical and proximate composition of Sesame.

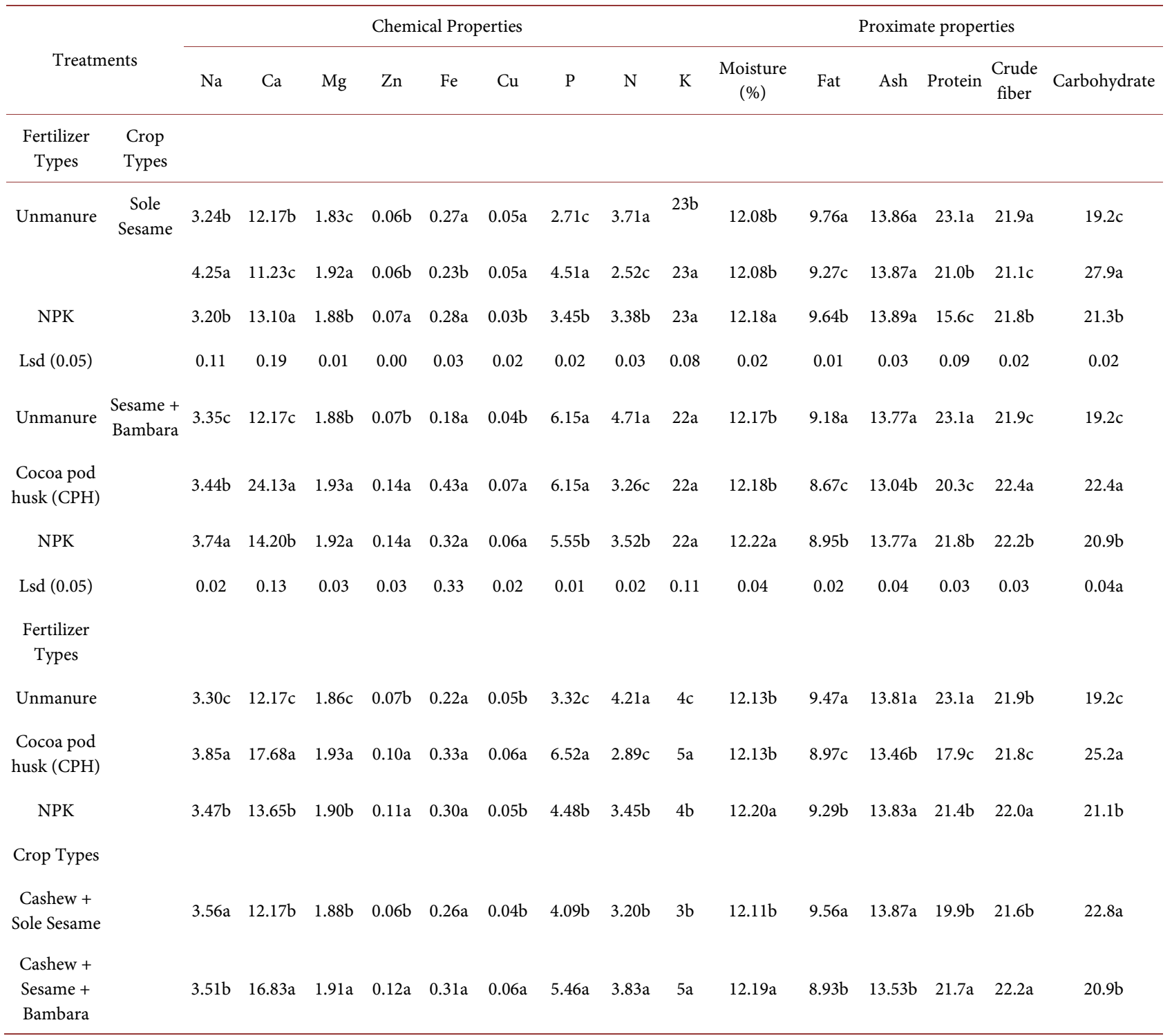

Table 4. Effect of organic fertilizer (Fert Plus) on Sesame leaf nutrient composition.

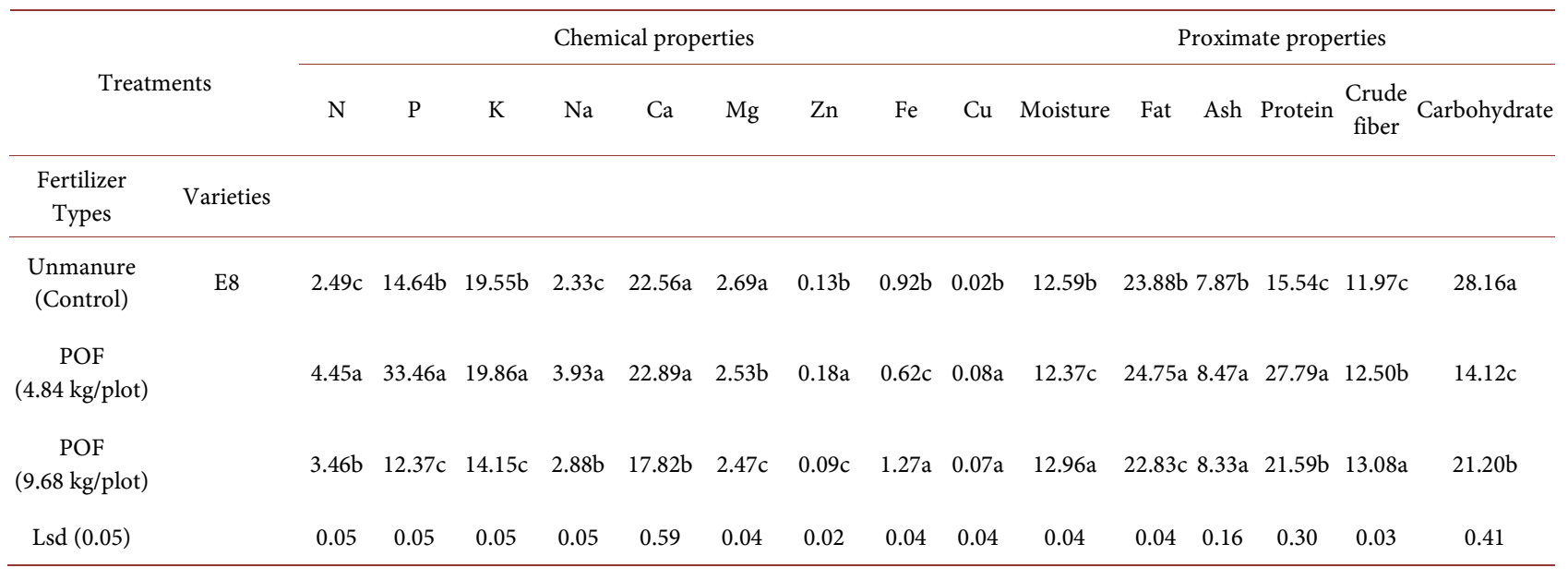




\section{Continued}

\begin{tabular}{|c|c|c|c|c|c|c|c|c|c|c|c|c|c|c|c|}
\hline $\begin{array}{l}\text { Unmanure } \\
\text { (Control) }\end{array}$ & NCRIBen04E & $3.68 \mathrm{~b}$ & $15.10 \mathrm{~b}$ & $16.63 b$ & $2.71 \mathrm{~b}$ & $22.46 \mathrm{a}$ & $2.94 a$ & $0.15 b$ & $0.65 c$ & $0.05 b$ & $12.77 \mathrm{~b}$ & 22.78 c $9.06 \mathrm{a}$ & $22.96 b$ & $11.77 \mathrm{c}$ & $20.66 \mathrm{a}$ \\
\hline $\begin{array}{c}\text { POF } \\
(4.84 \mathrm{~kg} / \text { plot })\end{array}$ & & $3.48 \mathrm{c}$ & $13.65 c$ & $15.35 c$ & $2.38 \mathrm{c}$ & $18.72 \mathrm{c}$ & $2.58 \mathrm{~b}$ & $0.06 \mathrm{c}$ & $1.15 \mathrm{a}$ & $0.06 \mathrm{a}$ & $12.23 \mathrm{c}$ & $23.85 \mathrm{a} 8.28 \mathrm{c}$ & $21.70 c$ & $13.58 \mathrm{a}$ & $20.35 b$ \\
\hline $\begin{array}{c}\text { POF } \\
(9.68 \mathrm{~kg} / \text { plot })\end{array}$ & & $4.45 \mathrm{a}$ & $18.85 \mathrm{a}$ & $18.64 \mathrm{a}$ & $3.40 \mathrm{a}$ & $19.62 b$ & $2.56 \mathrm{~b}$ & $0.18 \mathrm{a}$ & $0.85 b$ & $0.05 b$ & $12.93 \mathrm{a}$ & $22.82 \mathrm{~b} 8.48 \mathrm{~b}$ & $22.75 a$ & $12.48 \mathrm{~b}$ & $15.55 \mathrm{c}$ \\
\hline Lsd (0.05) & & 0.02 & 0.03 & 0.03 & 0.12 & 0.02 & 0.03 & 0.02 & 0.01 & 0.01 & 0.02 & $0.02 \quad 0.02$ & 0.11 & 0.02 & 0.09 \\
\hline \multicolumn{16}{|l|}{$\begin{array}{l}\text { Fertilizer } \\
\text { Types }\end{array}$} \\
\hline $\begin{array}{c}\text { Unmanure } \\
\text { (Control) }\end{array}$ & & $3.09 c$ & $14.87 \mathrm{c}$ & $18.09 \mathrm{a}$ & $2.52 \mathrm{~b}$ & $22.51 \mathrm{a}$ & $2.82 \mathrm{a}$ & $0.14 \mathrm{a}$ & $0.77 \mathrm{c}$ & $0.04 \mathrm{c}$ & $12.68 \mathrm{~b}$ & $23.33 \mathrm{~b} 8.47 \mathrm{a}$ & $19.25 c$ & $11.87 \mathrm{c}$ & $24.41 \mathrm{a}$ \\
\hline $\begin{array}{c}\text { POF } \\
(4.84 \mathrm{~kg} / \text { plot })\end{array}$ & & $3.97 \mathrm{a}$ & $23.56 \mathrm{a}$ & $17.60 \mathrm{~b}$ & $3.16 \mathrm{a}$ & $20.81 \mathrm{~b}$ & $2.56 \mathrm{~b}$ & $0.12 b$ & $0.89 b$ & $0.07 a$ & $12.30 \mathrm{c}$ & $24.30 \mathrm{a} 8.38 \mathrm{~b}$ & $24.74 \mathrm{a}$ & $13.04 \mathrm{a}$ & $17.24 \mathrm{c}$ \\
\hline $\begin{array}{c}\text { POF } \\
\text { (9.68 kg/plot) }\end{array}$ & & $3.95 b$ & $15.61 \mathrm{~b}$ & $16.40 \mathrm{c}$ & $3.14 \mathrm{a}$ & $18.72 \mathrm{c}$ & $2.52 \mathrm{c}$ & $0.13 a$ & $1.06 \mathrm{a}$ & $0.06 \mathrm{~b}$ & $12.95 \mathrm{a}$ & $22.82 \mathrm{c} 8.41 \mathrm{ab}$ & $24.67 \mathrm{~b}$ & $12.78 \mathrm{~b}$ & $18.38 \mathrm{~b}$ \\
\hline \multicolumn{16}{|l|}{ Crop Types } \\
\hline E8 & & $3.47 \mathrm{~b}$ & $20.16 \mathrm{a}$ & $17.85 \mathrm{a}$ & $3.05 a$ & $21.09 \mathrm{a}$ & $2.57 \mathrm{~b}$ & $0.13 \mathrm{a}$ & $0.94 \mathrm{a}$ & $0.06 \mathrm{a}$ & $12.64 \mathrm{a}$ & $23.82 \mathrm{a} 8.22 \mathrm{~b}$ & $21.64 \mathrm{~b}$ & $12.52 b$ & $21.16 \mathrm{a}$ \\
\hline $\begin{array}{c}\text { NCRIBen04E } \\
\text { (Ex-Sudan) }\end{array}$ & & $3.87 \mathrm{a}$ & $15.87 \mathrm{~b}$ & $16.8 \mathrm{~b}$ & $2.83 b$ & $20.27 b$ & $2.69 \mathrm{a}$ & $0.13 \mathrm{a}$ & $0.88 \mathrm{~b}$ & $0.05 a$ & $12.64 \mathrm{a}$ & $23.15 b 8.618 a$ & $24.14 \mathrm{a}$ & $12.61 \mathrm{a}$ & $18.85 b$ \\
\hline
\end{tabular}

Table 5. Manuring effect on Bambara Leaf nutrient composition.

\begin{tabular}{|c|c|c|c|c|c|c|c|c|c|c|c|c|c|c|c|c|}
\hline \multirow{2}{*}{ Treatments } & & \multicolumn{9}{|c|}{ Chemical properties } & \multicolumn{6}{|c|}{ Proximate properties } \\
\hline & & \multirow{2}{*}{$\mathrm{Na}$} & \multirow{2}{*}{$\mathrm{Ca}$} & \multirow{3}{*}{$\mathrm{Mg}$} & \multirow{3}{*}{$\mathrm{Zn}$} & \multirow{3}{*}{$\mathrm{Fe}$} & \multirow{3}{*}{$\mathrm{Cu}$} & \multirow{3}{*}{$\mathrm{P}$} & \multirow{3}{*}{$\mathrm{N}$} & \multirow{3}{*}{$\mathrm{K}$} & \multirow{3}{*}{ Moisture } & \multirow{3}{*}{ Fat } & \multirow{3}{*}{ Ash } & \multirow{3}{*}{ protein } & \multirow{3}{*}{$\begin{array}{l}\text { Crude } \\
\text { fiber }\end{array}$} & \multirow{3}{*}{ Carbohydrate } \\
\hline Fertilizer & Crop & & & & & & & & & & & & & & & \\
\hline Types & Types & & & & & & & & & & & & & & & \\
\hline Unmanure & $\begin{array}{c}\text { Sole } \\
\text { Bambara }\end{array}$ & $3.85 \mathrm{a}$ & $35.33 b$ & $1.94 \mathrm{a}$ & $0.08 \mathrm{a}$ & $0.24 \mathrm{~b}$ & $0.03 b$ & $2.82 \mathrm{c}$ & $3.19 \mathrm{a}$ & $39.09 c$ & $9.44 \mathrm{~b}$ & $8.88 \mathrm{a}$ & $15.98 \mathrm{~b}$ & $19.88 \mathrm{a}$ & $31.08 \mathrm{~b}$ & $14.73 \mathrm{c}$ \\
\hline $\begin{array}{c}\text { Cocoa pod husk } \\
(\mathrm{CPH})\end{array}$ & & $3.63 \mathrm{a}$ & $23.70 \mathrm{c}$ & $1.92 \mathrm{~b}$ & $0.09 \mathrm{a}$ & $0.24 \mathrm{~b}$ & $0.07 \mathrm{a}$ & $3.38 \mathrm{~b}$ & $2.25 \mathrm{c}$ & $48.30 \mathrm{a}$ & $9.95 \mathrm{a}$ & $8.58 \mathrm{~b}$ & $15.87 \mathrm{~b}$ & $14.02 \mathrm{c}$ & $29.87 \mathrm{c}$ & $21.71 \mathrm{a}$ \\
\hline N.P.K & & 3.67 & $64.50 \mathrm{a}$ & $1.87 \mathrm{c}$ & $0.07 \mathrm{a}$ & $0.28 \mathrm{a}$ & $0.06 \mathrm{a}$ & $4.62 \mathrm{a}$ & $2.58 \mathrm{~b}$ & $40.57 b$ & $9.04 \mathrm{c}$ & $8.57 \mathrm{~b}$ & $16.16 \mathrm{a}$ & $16.10 \mathrm{~b}$ & $31.54 \mathrm{a}$ & $18.59 b$ \\
\hline Unmanure & $\begin{array}{l}\text { Bambara } \\
+ \text { Sesame }\end{array}$ & $4.40 \mathrm{a}$ & $20.42 \mathrm{c}$ & $1.89 \mathrm{a}$ & $0.07 \mathrm{a}$ & $0.35 \mathrm{a}$ & $0.03 b$ & $2.18 \mathrm{c}$ & $2.86 \mathrm{c}$ & $36.47 a$ & $8.87 b$ & $8.83 b$ & $15.67 \mathrm{~b}$ & $17.85 \mathrm{c}$ & $30.78 \mathrm{~b}$ & $17.99 \mathrm{a}$ \\
\hline $\begin{array}{l}\text { Cocoa pod husks } \\
(\mathrm{CPH})\end{array}$ & & $3.92 b$ & $40.14 \mathrm{~b}$ & $1.88 \mathrm{~b}$ & $0.09 \mathrm{a}$ & $0.28 b$ & $0.05 \mathrm{ab}$ & $5.28 \mathrm{a}$ & $3.28 \mathrm{c}$ & $30.57 b$ & $8.75 c$ & $8.75 b$ & $16.30 \mathrm{a}$ & $20.45 b$ & $31.18 \mathrm{a}$ & $14.57 b$ \\
\hline N.P.K & & $4.50 \mathrm{a}$ & $83.50 \mathrm{a}$ & $1.88 \mathrm{~b}$ & $0.09 \mathrm{a}$ & $0.27 b$ & $0.07 \mathrm{a}$ & $4.38 \mathrm{~b}$ & $3.39 \mathrm{a}$ & $22.56 c$ & $9.74 \mathrm{a}$ & $8.88 \mathrm{a}$ & $15.89 \mathrm{~b}$ & $21.13 a$ & $30.07 \mathrm{c}$ & $14.28 \mathrm{~b}$ \\
\hline Lsd (0.05) & & 0.22 & 0.10 & 0.01 & 0.02 & 0.03 & 0.02 & 0.01 & 0.08 & 0.38 & 0.03 & 0.05 & 0.25 & 0.51 & 0.01 & 0.78 \\
\hline Fertilizer Types & & & & & & & & & & & & & & & & \\
\hline
\end{tabular}




\section{Continued}

\begin{tabular}{|c|c|c|c|c|c|c|c|c|c|c|c|c|c|c|}
\hline Unmanure & $4.13 \mathrm{a}$ & $27.88 \mathrm{c}$ & $1.92 \mathrm{a}$ & $0.08 \mathrm{a}$ & $0.29 \mathrm{a}$ & $0.03 b$ & $2.78 \mathrm{c}$ & $3.02 \mathrm{a}$ & $37.77 b$ & $9.16 \mathrm{c}$ & $8.86 \mathrm{a} 15.83 \mathrm{~b}$ & $18.87 \mathrm{a}$ & $30.93 a$ & $16.36 \mathrm{~b}$ \\
\hline $\begin{array}{c}\text { Cocoa pod husk } \\
(\mathrm{CPH})\end{array}$ & $3.78 b$ & $31.92 b$ & $1.90 \mathrm{~b}$ & $0.09 a$ & $0.26 c$ & $0.06 \mathrm{a}$ & $4.95 \mathrm{a}$ & $2.76 \mathrm{c}$ & $39.43 a$ & $9.35 b$ & $8.67 \mathrm{c} 16.09 \mathrm{a}$ & $17.23 \mathrm{c}$ & $30.53 c$ & $18.14 \mathrm{a}$ \\
\hline N.P.K & $4.09 \mathrm{a}$ & $74.00 \mathrm{a}$ & $1.88 \mathrm{c}$ & $0.08 \mathrm{a}$ & $0.28 \mathrm{~b}$ & $0.06 \mathrm{a}$ & $3.60 \mathrm{~b}$ & $2.98 \mathrm{~b}$ & $31.56 \mathrm{c}$ & $9.39 \mathrm{a}$ & $8.73 b \quad 16.02 a$ & $18.62 b$ & $30.81 \mathrm{~b}$ & $16.44 \mathrm{~b}$ \\
\hline \multicolumn{15}{|l|}{ Crop Types } \\
\hline $\begin{array}{c}\text { Cashew + Sole } \\
\text { Bambara }\end{array}$ & $3.44 \mathrm{~b}$ & $40.84 \mathrm{~b}$ & $1.90 \mathrm{a}$ & $0.08 \mathrm{a}$ & $0.23 b$ & $0.03 a$ & $3.56 \mathrm{~b}$ & $2.66 \mathrm{~b}$ & $42.44 a$ & $8.97 b$ & $7.52 \mathrm{a} 15.15 \mathrm{~b}$ & $17.98 \mathrm{~b}$ & $35.40 \mathrm{a}$ & $14.99 \mathrm{a}$ \\
\hline $\begin{array}{c}\text { Cashew }+ \\
\text { Bambara }+ \text { Sesame }\end{array}$ & $4.01 \mathrm{a}$ & $47.83 \mathrm{a}$ & $1.86 \mathrm{~b}$ & $0.09 a$ & $0.27 \mathrm{a}$ & $0.04 \mathrm{a}$ & $3.93 \mathrm{a}$ & $3.14 \mathrm{a}$ & $29.61 b$ & $9.29 \mathrm{a}$ & $7.43 \mathrm{~b} 15.18 \mathrm{a}$ & $19.22 \mathrm{a}$ & $34.00 \mathrm{a}$ & $14.88 \mathrm{a}$ \\
\hline
\end{tabular}

Means with the same letters along each column are not significantly different using Lsd at 0.05 level of probability.

Table 6. Effects of organic fertilizer onBambara Leaf nutrient composition.

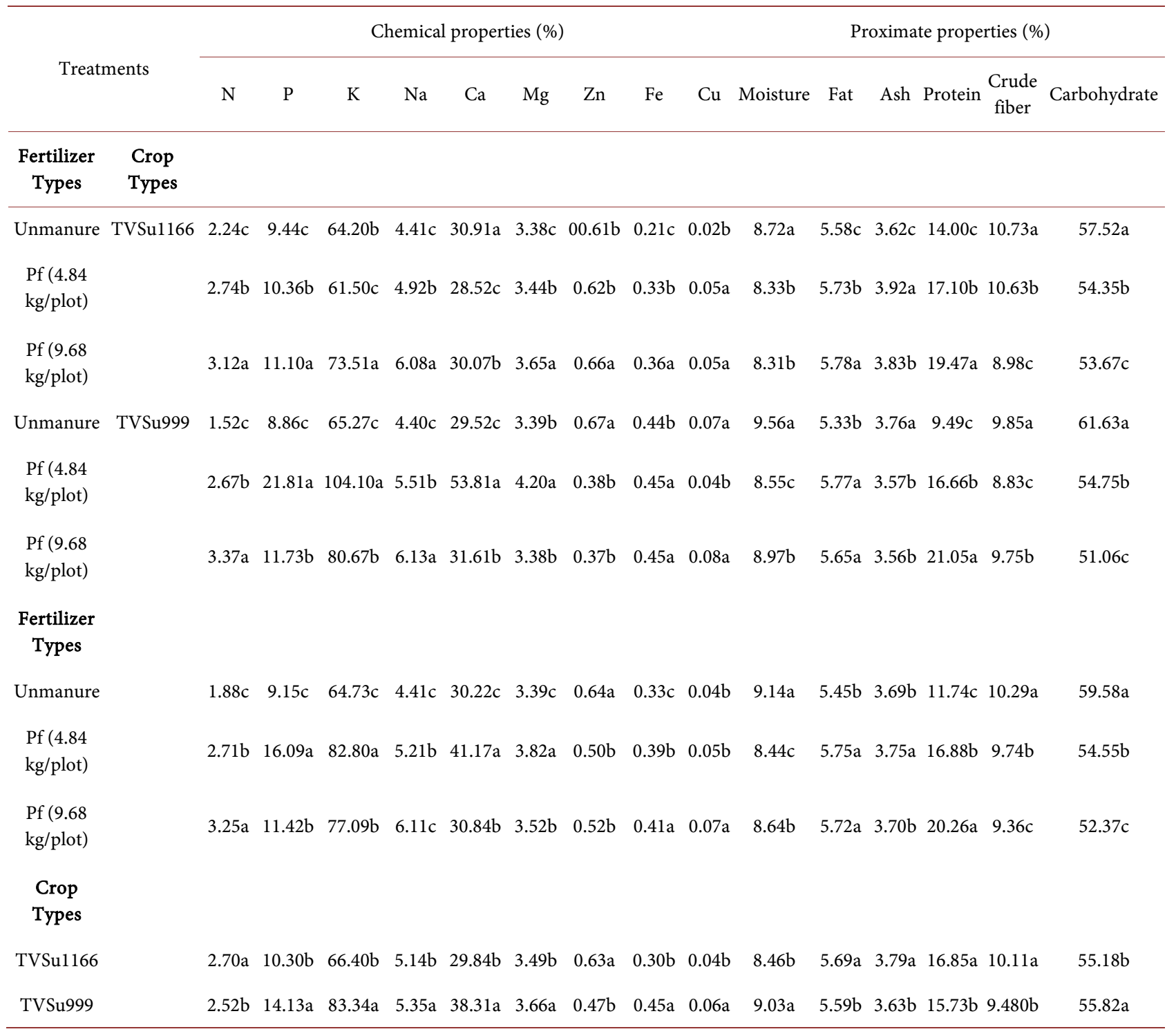

Means with the same letters along each column are not significantly different using Lsd at 0.05 level of probability. 
significant for the un-manure (control) and $\mathrm{CPH}$ treatment $\mathrm{P}$ and $\mathrm{K}$ uptake were enhanced NPK fertilizer. Sole Bambara leaves had higher N and $\mathrm{K}$ contents compare to the Bambara planted with Sesame. The Bambara variety TVSu1166 had significantly higher contents of $\mathrm{P}$, fat, crude fiber and carbohydrate and was significant in the un-manure plot. Application of $4.84 \mathrm{~kg}$ pelletized fertilizer enhanced $\mathrm{N}, \mathrm{Na}, \mathrm{Ca}, \mathrm{Fe}, \mathrm{Cu}$, Ash and protein content, while $9.68 \mathrm{~kg}$ pelletized fertilizer significantly influence $\mathrm{K}, \mathrm{Mg}, \mathrm{Zn}$ and moisture content in the Bambara nut. Bambara variety TVSu1 166 had higher K up-take and Nitrogen harvest index (NHI), which were significantly different from $9.68 \mathrm{~kg}$ pelletized fertilizer. Bambara variety Tvsu999 was significant in Nitrogen (N), Phosphorus (P), and Potassium (K) with $4.84 \mathrm{Kg}$ pelletized fertilizer treatment apart from the NHI (Table 6).

Application of NPK fertilizer significantly influenced most of the nutrient use efficiency parameters measured. Agronomy Efficiency (AE), Apparent recovery Efficiency (RE), Apparent recovery Efficiency by difference (RE\%), Physiological Efficiency (PE), Utilization Efficiency (UE), Internal utilization Efficiency (IE) and Partial Fertilizer productivity (PFP) were significantly high in the intercrops, apart from the $\mathrm{N}$ removed during harvest in Sole Sesame (Table 7 and Table 8). Similar trends were observed in the Sesame + Bambara plots, apart for Internal Utilization Efficiency which was higher in the un-manure (control)

Table 7. Manuring effects on agronomic and physiological efficiencies of $\mathrm{N}$ use by Sesame.

\begin{tabular}{|c|c|c|c|c|c|c|c|c|c|}
\hline Treatme & & $\begin{array}{c}\text { Agronomy } \\
\text { Efficiency-(AE) } \\
\mathrm{Kg}\end{array}$ & $\begin{array}{c}\text { Apparent } \\
\text { Recovery } \\
\text { Efficiency } \\
\text { (RE) }\end{array}$ & $\begin{array}{c}\text { Apparent } \\
\text { Recovery } \\
\text { Efficiency } \\
\text { By Difference }\end{array}$ & $\begin{array}{c}\text { Physiological } \\
\text { Efficiency } \\
\text { (PE) }\end{array}$ & $\begin{array}{c}\text { Utilization } \\
\text { Efficiency } \\
\text { (UE) }\end{array}$ & $\begin{array}{c}\mathrm{N} \\
\text { removed } \\
\text { @harvest }\end{array}$ & $\begin{array}{l}\text { Internal } \\
\text { Utilization } \\
\text { Efficiency } \\
\quad \text { (IE) }\end{array}$ & $\begin{array}{c}\text { Partial-Fertilizer } \\
\text { Productivity } \\
\text { of Fertilizer } \\
\mathrm{N}\left(\mathrm{PFP}_{\mathrm{N}}\right)\end{array}$ \\
\hline Fertilizer Types & Crop Types & & & & & & & & \\
\hline Unmanure & & $0.00 \mathrm{~b}$ & $0.00 \mathrm{~b}$ & $0.00 \mathrm{~b}$ & $0.00 c$ & $0.00 \mathrm{~b}$ & $0.00 \mathrm{a}$ & $0.01 \mathrm{c}$ & $0.00 c$ \\
\hline Cocoa pod husk & Sole Sesame & $0.00 \mathrm{~b}$ & $0.07 \mathrm{~b}$ & $0.07 b$ & $0.01 \mathrm{~b}$ & $0.00 \mathrm{~b}$ & $0.01 \mathrm{a}$ & $0.01 \mathrm{~b}$ & $0.01 \mathrm{~b}$ \\
\hline NPK & & $0.01 \mathrm{a}$ & $0.53 \mathrm{a}$ & $1.09 \mathrm{a}$ & $0.02 \mathrm{a}$ & $0.01 \mathrm{a}$ & $0.01 \mathrm{a}$ & $0.01 \mathrm{a}$ & $0.021 \mathrm{a}$ \\
\hline Unmanure & & $0.00 \mathrm{~b}$ & $0.00 c$ & $0.00 \mathrm{~b}$ & $0.00 \mathrm{~b}$ & $0.00 \mathrm{~b}$ & $0.00 \mathrm{c}$ & $0.01 \mathrm{a}$ & $0.00 c$ \\
\hline Cocoa pod husk & $\begin{array}{l}\text { Sesame + } \\
\text { Bambara }\end{array}$ & $0.00 \mathrm{~b}$ & $0.04 \mathrm{~b}$ & $0.03 b$ & $0.01 \mathrm{a}$ & 0.00 & $0.01 b$ & $0.01 \mathrm{ab}$ & $0.01 \mathrm{~b}$ \\
\hline NPK & & $0.01 \mathrm{a}$ & $0.29 \mathrm{a}$ & $0.19 \mathrm{a}$ & $0.01 \mathrm{a}$ & $0.01 \mathrm{a}$ & $0.02 \mathrm{a}$ & $0.01 \mathrm{~b}$ & $0.02 \mathrm{a}$ \\
\hline \multicolumn{10}{|l|}{ Fertilizer Types } \\
\hline Unmanure & & $0.00 \mathrm{c}$ & $0.00 \mathrm{c}$ & $0.00 \mathrm{c}$ & $0.00 \mathrm{c}$ & $0.00 \mathrm{c}$ & $0.00 c$ & $35.43 \mathrm{~b}$ & $0.00 \mathrm{c}$ \\
\hline Cocoa pod husk & & $4.35 \mathrm{~b}$ & $0.05 \mathrm{~b}$ & $20.59 b$ & $0.01 \mathrm{~b}$ & $4.54 \mathrm{~b}$ & $-47.33 b$ & $50.84 \mathrm{a}$ & $23.02 \mathrm{~b}$ \\
\hline NPK & & $53.44 \mathrm{a}$ & $0.64 \mathrm{a}$ & $52.89 a$ & $0.01 \mathrm{a}$ & $53.44 \mathrm{a}$ & $-55.50 \mathrm{a}$ & $50.92 \mathrm{a}$ & $140.44 a$ \\
\hline \multicolumn{10}{|l|}{ Crop Types } \\
\hline Sole Sesame & & $10.48 \mathrm{~b}$ & $0.38 \mathrm{a}$ & $13.55 b$ & $0.01 \mathrm{a}$ & $10.48 \mathrm{~b}$ & $16.78 \mathrm{~b}$ & $49.90 \mathrm{a}$ & $53.61 \mathrm{~b}$ \\
\hline Sesame + Bambara & & $28.04 a$ & $0.07 \mathrm{~b}$ & $35.44 \mathrm{a}$ & $0.01 \mathrm{~b}$ & $28.17 \mathrm{a}$ & $22.22 \mathrm{a}$ & $41.57 \mathrm{~b}$ & $55.361 \mathrm{a}$ \\
\hline Fertilizer Types & & 1.19 & 0.05 & 0.26 & 0.01 & 1.19 & 0.83 & 1.74 & 0.78 \\
\hline Crop Types & & 1.59 & 0.02 & 0.25 & 0.01 & 1.59 & 0.36 & 1.26 & 0.74 \\
\hline
\end{tabular}


Table 8. Effects of organic fertilizer on agronomic and physiological efficiencies of $\mathrm{N}$ use by Sesame.

\begin{tabular}{|c|c|c|c|c|c|c|c|c|c|c|c|c|c|}
\hline \multicolumn{3}{|c|}{ Treatments } & \multirow[t]{2}{*}{$\begin{array}{c}\text { Agronomy } \\
\text { Efficiency } \\
\text { (AE) }\end{array}$} & \multirow[t]{2}{*}{$\begin{array}{c}\text { Recovery } \\
\text { Efficiency } \\
\text { (RE) }\end{array}$} & $\begin{array}{cc}\text { Recovery } \\
\text { y } \\
\text { Efficiency by } \\
\text { Difference (RE) }\end{array}$ & \multicolumn{2}{|c|}{$\begin{array}{l}\text { Physiology } \\
\text { Efficiency } \\
\text { (PE) }\end{array}$} & \multicolumn{2}{|c|}{$\begin{array}{l}\text { Utilization } \\
\text { Efficiency } \\
\quad(\mathrm{UE})\end{array}$} & $\begin{array}{l}\text { N Remove } \\
\text { with } \\
\text { Harvest }\end{array}$ & \multicolumn{2}{|c|}{$\begin{array}{c}\text { Internal } \\
\text { Utilization } \\
\text { Efficiency (IE) }\end{array}$} & \multirow[t]{2}{*}{$\begin{array}{l}\text { Partial Factor } \\
\text { Productivity } \\
\text { (PFP) }\end{array}$} \\
\hline \multicolumn{2}{|c|}{ Fertilizer Types } & Crop Types & & & & & & & & & & & \\
\hline \multicolumn{2}{|c|}{ Unmanure } & & $0.00 \mathrm{c}$ & $0.00 c$ & $0.00 c$ & \multicolumn{2}{|c|}{$0.00 \mathrm{c}$} & \multicolumn{2}{|c|}{$0.00 \mathrm{c}$} & \multicolumn{2}{|c|}{$0.00 \mathrm{~b}$} & $1.22 \mathrm{c}$ & $0.00 \mathrm{c}$ \\
\hline \multicolumn{2}{|c|}{$\operatorname{Pf}(4.84 \mathrm{~kg} / \mathrm{plot})$} & \multirow[t]{2}{*}{ E8 } & $11.84 \mathrm{a}$ & $3.91 \mathrm{a}$ & $391.07 \mathrm{a}$ & \multicolumn{2}{|c|}{$19.78 \mathrm{a}$} & \multicolumn{2}{|c|}{$234.19 \mathrm{a}$} & \multicolumn{2}{|c|}{$0.78 \mathrm{a}$} & $2.86 \mathrm{a}$ & $1.27 \mathrm{~b}$ \\
\hline \multicolumn{2}{|c|}{$\operatorname{Pf}(9.68$ kg/plot $)$} & & $7.41 \mathrm{~b}$ & $3.58 \mathrm{~b}$ & $357.94 \mathrm{~b}$ & \multicolumn{2}{|c|}{$6.24 \mathrm{~b}$} & \multicolumn{2}{|c|}{$46.40 \mathrm{~b}$} & $1.32 \mathrm{a}$ & $2 \mathrm{a}$ & $1.93 \mathrm{~b}$ & $1.73 \mathrm{a}$ \\
\hline \multicolumn{2}{|c|}{ Unmanure } & \multirow{3}{*}{$\begin{array}{l}\text { NCRIBen04E } \\
\text { (Ex-Sudan) }\end{array}$} & $0.00 \mathrm{c}$ & $0.00 \mathrm{~b}$ & $0.00 \mathrm{~b}$ & \multicolumn{2}{|c|}{$0.00 \mathrm{a}$} & 0.00 & & 0.00 & $0 c$ & $1.28 \mathrm{c}$ & $0.00 c$ \\
\hline $\operatorname{Pf}(4.84 \mathrm{~kg} / \mathrm{h}$ & plot) & & $7.44 \mathrm{~b}$ & $3.35 \mathrm{a}$ & $334.80 \mathrm{a}$ & 22.8 & & 170. & & 0.75 & $5 b$ & $2.03 \mathrm{~b}$ & $1.74 \mathrm{a}$ \\
\hline $\mathrm{Pf}(9.68 \mathrm{~kg} / \mathrm{r}$ & plot) & & $15.52 \mathrm{a}$ & $3.39 \mathrm{a}$ & $339.30 \mathrm{a}$ & 14.9 & & 236. & & 1.18 & $8 \mathrm{a}$ & $4.25 \mathrm{a}$ & $1.65 \mathrm{~b}$ \\
\hline Fertilizer $\mathrm{T}_{y}$ & pes & & & & & & & & & & & & \\
\hline Un manu & & & $0.00 c$ & $0.00 \mathrm{c}$ & $0.00 c$ & 0.00 & & 0.0 & & 0.00 & $0 \mathrm{~b}$ & $1.25 \mathrm{c}$ & $0.00 \mathrm{c}$ \\
\hline $\operatorname{Pf}(4.84 \mathrm{~kg} / \mathrm{r}$ & plot) & & $7.42 b$ & $3.46 \mathrm{~b}$ & $346.37 \mathrm{~b}$ & 14.5 & & 108. & & 1.03 & $3 a$ & $1.98 \mathrm{~b}$ & $1.73 \mathrm{a}$ \\
\hline $\operatorname{Pf}(9.68 \mathrm{~kg} / \mathrm{r}$ & plot) & & $13.67 \mathrm{a}$ & $3.65 \mathrm{a}$ & $365.19 \mathrm{a}$ & 17.3 & & 235 . & & 0.98 & $8 \mathrm{a}$ & $3.56 \mathrm{a}$ & $1.46 \mathrm{~b}$ \\
\hline Crop Typ & & & & & & & & & & & & & \\
\hline E8 & & & $6.43 b$ & $2.42 \mathrm{a}$ & $241.96 a$ & 14.2 & & 134. & & 0.51 & $1 \mathrm{~b}$ & $2.03 \mathrm{~b}$ & $1.00 \mathrm{~b}$ \\
\hline NCRIBen0 & & & $7.64 \mathrm{a}$ & $2.32 \mathrm{a}$ & $232.42 \mathrm{a}$ & 7.06 & & 94.2 & & 0.83 & $3 a$ & $2.49 \mathrm{a}$ & $1.12 \mathrm{a}$ \\
\hline Treatme & ents & $\begin{array}{c}\text { Agronomic } \\
\text { Efficiency } \\
\text { (AE) }\end{array}$ & $\begin{array}{l}\text { Agronomic } \\
\text { N use } \\
\text { Efficiency } \\
\text { (ANUE) }\end{array}$ & $\begin{array}{l}\text { Apparent } \\
\text { Recovery } \\
\text { Efficiency } \\
\text { (RE) }\end{array}$ & $\begin{array}{c}\text { Apparent } \\
\text { Recovery } \\
\text { Efficiency by } \\
\text { Difference\% }\end{array}$ & $\begin{array}{l}\text { Physiology } \\
\text { Efficiency } \\
\text { (PE) }\end{array}$ & $\begin{array}{r}\text { Ferti } \\
\mathrm{U} \\
\text { Effici } \\
(\mathrm{FA}\end{array}$ & $\begin{array}{l}\text { tilizer } \\
\text { Jse } \\
\text { ciency } \\
\text { AE) }\end{array}$ & $\begin{array}{r}\mathrm{N} \\
\text { Remoy } \\
\text { @ harv }\end{array}$ & vest & $\begin{array}{l}\text { Internal } \\
\text { Utilization } \\
\text { Efficiency } \\
\text { (IE) }\end{array}$ & $\begin{array}{l}\text { Utilization } \\
\text { Efficiency } \\
(\mathrm{EU})\end{array}$ & $\begin{array}{c}\text { Partial } \\
\text { Factor } \\
\text { Production } \\
(\mathrm{PFP})\end{array}$ \\
\hline $\begin{array}{c}\text { Fertilizer } \\
\text { Types }\end{array}$ & $\begin{array}{l}\text { Crop } \\
\text { Types }\end{array}$ & & & & & & & & & & & & \\
\hline Unmanure & $\begin{array}{c}\text { Sole } \\
\text { Bambara }\end{array}$ & $0.00 \mathrm{~b}$ & $0.00 \mathrm{~b}$ & $0.00 c$ & $0.00 \mathrm{c}$ & $0.00 \mathrm{~b}$ & & $00 \mathrm{~b}$ & 0.00 & & $304.80 \mathrm{~b}$ & $0.00 \mathrm{~b}$ & $0.00 \mathrm{c}$ \\
\hline $\begin{array}{c}\text { Cocoa pod } \\
\text { husk }\end{array}$ & & $3.19 \mathrm{~b}$ & $3.19 b$ & $318.7 \mathrm{~b}$ & $19.40 \mathrm{a}$ & $0.02 \mathrm{~b}$ & & $71 b$ & -1.68 & & $535.73 a$ & $318.7 \mathrm{~b}$ & $9.33 b$ \\
\hline NPK & & $12.55 \mathrm{a}$ & $12.55 \mathrm{a}$ & $1254.5 \mathrm{a}$ & $11.10 \mathrm{~b}$ & $1.06 \mathrm{a}$ & & $01 \mathrm{a}$ & -2.07 & & $540.23 a$ & $1254.5 \mathrm{a}$ & $38.84 a$ \\
\hline Unmanure & $\begin{array}{l}\text { Bambara } \\
+ \text { Sesame }\end{array}$ & $0.00 \mathrm{a}$ & $0.00 \mathrm{a}$ & $0.00 \mathrm{a}$ & $0.00 c$ & $0.00 \mathrm{~b}$ & & $00 \mathrm{~b}$ & 0.00 & & $105.48 \mathrm{~b}$ & $0,00 \mathrm{a}$ & $0.00 \mathrm{c}$ \\
\hline $\begin{array}{c}\text { Cocoa pod } \\
\text { husk }\end{array}$ & & $4.52 \mathrm{a}$ & $4.52 \mathrm{a}$ & $451.6 \mathrm{a}$ & $14.64 \mathrm{a}$ & $0.09 b$ & & $42 \mathrm{a}$ & -2.76 & & $218.38 \mathrm{a}$ & $90.32 \mathrm{a}$ & $13.32 \mathrm{~b}$ \\
\hline NPK & & $0.79 \mathrm{a}$ & $0.79 \mathrm{a}$ & $78.7 \mathrm{a}$ & $4.02 \mathrm{~b}$ & $0.29 \mathrm{a}$ & & $30 \mathrm{~b}$ & -0.49 & & $113.30 \mathrm{~b}$ & $15.75 \mathrm{a}$ & $38.52 \mathrm{a}$ \\
\hline $\begin{array}{c}\text { Fertilizer } \\
\text { Types }\end{array}$ & & & & & & & & & & & & & \\
\hline Unmanure & & $0.00 \mathrm{~b}$ & $0.00 \mathrm{~b}$ & $0.00 \mathrm{~b}$ & $0.00 c$ & $0.00 \mathrm{~b}$ & & $00 c$ & 0.00 & & $205.14 \mathrm{c}$ & $0.00 \mathrm{~b}$ & $0.00 \mathrm{c}$ \\
\hline $\begin{array}{c}\text { Cocoa pod } \\
\text { husk }\end{array}$ & & $3.85 \mathrm{ab}$ & $3.85 \mathrm{ab}$ & $385.1 \mathrm{ab}$ & $17.03 \mathrm{a}$ & $0.056 \mathrm{~b}$ & & $06 a$ & -2.22 & & $377.06 \mathrm{a}$ & $204.5 b$ & $11.324 \mathrm{~b}$ \\
\hline NPK & & $6.67 \mathrm{a}$ & $6.67 \mathrm{a}$ & $666.6 a$ & $7.56 \mathrm{~b}$ & $0.24 b$ & & $66 a$ & -1.28 & & $326.76 b$ & $635.1 \mathrm{a}$ & $38.68 \mathrm{a}$ \\
\hline Crop Types & & & & & & & & & & & & & \\
\hline Sole Bambara & & $5.24 \mathrm{a}$ & $5.24 \mathrm{a}$ & $524.4 \mathrm{a}$ & 10.17 & $0.36 \mathrm{a}$ & & $24 \mathrm{a}$ & -1.25 & & $460.25 a$ & $524.4 \mathrm{a}$ & $16.06 \mathrm{a}$ \\
\hline $\begin{array}{c}\text { Bambara }+ \\
\text { Sesame }\end{array}$ & & $1.77 \mathrm{~b}$ & $1.77 \mathrm{a}$ & $176.8 \mathrm{a}$ & 6.22 & $0.13 b$ & & $24 \mathrm{~b}$ & -1.08 & & $145.72 b$ & $35.4 \mathrm{~b}$ & $17.28 \mathrm{a}$ \\
\hline $\begin{array}{c}\text { Fertilizer } \\
\text { Types }\end{array}$ & & 2.37 & 2.37 & 236.70 & 0.53 & 0.03 & & .38 & 0.05 & & 12.16 & 130.18 & 0.19 \\
\hline Crop Types & & 2.15 & 2.15 & 215.10 & 0.57 & 0.07 & & .43 & 0.07 & & 35.99 & 172.49 & 0.58 \\
\hline
\end{tabular}


plants. Fertilizer type affected nutrient use efficiency parameters measured. NPK fertilizer promoted these parameters compared to $\mathrm{CPH}$ and un-manure plots. Sole Sesame plants had significantly higher RE, PE, UE PFP while Sesame + Bambara significant improved AE, RE, UE, N-removed at harvest PFP comparable to the sole Sesame plants. However, in 2014 no significant differences amongst the parameter measured, apart from PFP for sole Sesame plants. The combination of Sesame + Bambara with NPK fertilizer had significantly higher AE, RE, UE, N-removed at harvest and PFP. NPK fertilizer treatment plants had a significantly higher value of compared to $\mathrm{CPH}$ manure and the un-manure plants. Sole Sesame significantly influence agronomy efficiency (AE), utilization efficiency (UE), internal efficiency (IE) and partial factor productivity (PFP). Sole Bambara under N.P.K fertilizer had higher N-removed at harvest and apparent recovery by difference (RE\%). Bambara + Sesame under cocoa pod husk $(\mathrm{CPH})$ manure had enhanced apparent recovery efficiency by difference (RE\%), fertilizer use efficiency (FAE) and internal utilization efficiency (IE). NPK fertilizer enhanced Physiology efficiency (PE) and Partial factor productivity. Fertilizer type affected significantly AE, agronomic $\mathrm{N}$-use efficiency (ANUE), RE, UE and PFP for 2013. CPH manure treatment significantly influence RE\%, PE and IE. The N-remove at harvest was significantly higher in the un-manure plants (control). Sole Bambara significantly influenced AE, RE\%, PE, FAE, IE and UE. Bambara + Sesame had significantly enhanced N (removed at harvest). Application of fertilizers for 2014 experimental year, significantly improved AE and RE, however $\mathrm{CPH}$ manure treatment influenced ANUE, RE\%, FAE, UE and PEP significantly. Crop type affected AE, ANUE, RE, RE\%, UE, sole Bambara had higher values of most of the parameters measured compared to mixtures of Bambara + sesame. Physiology efficiency (PE), and fertilizer use efficiency (FAE) was significantly different to Bambara + Sesame plants (Table 7 and Table 8). Bambara variety TVSu1166, that was treated with $9.68 \mathrm{~kg} /$ plot pelletized fertilizer had significantly higher Apparent Recovery Efficiency by difference (RE\%) and Partial Factor Productive (PFP), while $4.84 \mathrm{~kg}$ pelletized fertilizer affected Physiology Efficiency (PE). Bambara variety TVSu999 under $4.84 \mathrm{~kg}$ pelletized fertilizer had higher Agronomy Efficiency (AE), Apparent Recovery Efficiency (RE), Physiology Efficiency (PE) and Fertilizer Agronomy use Efficiency respectively (FAE). Application of $9.68 \mathrm{~kg}$ pelletized fertilizer significantly enhanced RE\%, IE and PFP AE, RE\%, FAE and EU experiment (Table 9 and Table 10). Application of $4.84 \mathrm{~kg}$ pelletized fertilizer influenced AE, RE\%, PE, FAE, EU, and PFP for 2014 experiment. Bambara variety TVSu1166 had significantly higher AE, RE\%, PE, FAE and EU, while TVSu999 variety influenced RE. Bambara variety TVSu1166 under application of $4.84 \mathrm{~kg}$ pelletized fertilizer enhanced IE, while $9.68 \mathrm{~kg}$ improved AE, RE, PE, FAE and EU respectively. Fertilizer effect type shows that $4.84 \mathrm{~kg}$ pelletized fertilizer influenced PFP, while 9.68 $\mathrm{kg} \mathrm{AE}, \mathrm{RE} \%, \mathrm{FAE}$ and EU respectively. Bambara variety TVSu999 compared to TVSu1166 had higher IUE (Table 9). Application of $4.84 \mathrm{~kg}$ organic fertilizer had higher values of most of the parameters measured expect for partial factor 
Table 9. Effects of organic fertilizer on agronomic and physiological efficiencies of $\mathrm{N}$ use by Bambara nut.

\begin{tabular}{|c|c|c|c|c|c|c|c|c|c|}
\hline \multicolumn{2}{|c|}{ Treatments } & \multirow{2}{*}{$\begin{array}{c}\text { Agronomic } \\
\text { Efficiency (AE) }\end{array}$} & \multirow{2}{*}{$\begin{array}{c}\text { Apparent } \\
\text { Recovery } \\
\text { Efficiency } \\
\text { (RE) }\end{array}$} & \multirow{2}{*}{$\begin{array}{l}\text { Apparent } \\
\text { Recovery } \\
\text { Efficiency by } \\
\text { Difference }\end{array}$} & \multirow{2}{*}{$\begin{array}{c}\text { Physiology } \\
\text { Efficiency } \\
\text { (PE) }\end{array}$} & \multirow{2}{*}{$\begin{array}{l}\text { Fertilizer } \\
\text { Use } \\
\text { Efficiency } \\
\text { (FAE) }\end{array}$} & \multirow{2}{*}{$\begin{array}{c}\text { Internal } \\
\text { Utilization } \\
\text { Efficiency } \\
\text { (IE) }\end{array}$} & \multirow{2}{*}{$\begin{array}{l}\text { Utilization } \\
\text { Efficiency } \\
\text { (EU) }\end{array}$} & \multirow{2}{*}{$\begin{array}{c}\text { Partial } \\
\text { Factor } \\
\text { Production } \\
\text { (PFP) }\end{array}$} \\
\hline Fertilizer Types & Crop Types & & & & & & & & \\
\hline Unmanure & TVSu1166 & $0.00 \mathrm{a}$ & $0.00 \mathrm{a}$ & $0.00 c$ & $0.00 \mathrm{~b}$ & $0.00 \mathrm{a}$ & $0.64 \mathrm{a}$ & $0.00 \mathrm{~b}$ & $0.00 \mathrm{c}$ \\
\hline Pf (4.84 kg/plot) & & $0.10 \mathrm{a}$ & $9.70 \mathrm{a}$ & $0.09 \mathrm{~b}$ & $1.06 \mathrm{a}$ & $0.10 \mathrm{a}$ & $0.68 \mathrm{a}$ & $10.37 \mathrm{a}$ & $0.72 b$ \\
\hline Pf (9.68 kg/plot) & & $0.07 \mathrm{a}$ & $6.93 a$ & $0.50 \mathrm{a}$ & $0.14 \mathrm{~b}$ & $0.01 \mathrm{a}$ & $0.67 \mathrm{a}$ & $1.92 \mathrm{~b}$ & $1.54 \mathrm{a}$ \\
\hline Un manure & TVSu999 & $0.00 \mathrm{~b}$ & $0.00 \mathrm{~b}$ & $0.00 c$ & $0.00 \mathrm{~b}$ & $0.00 \mathrm{~b}$ & $0.46 c$ & $0.00 \mathrm{a}$ & $0.00 c$ \\
\hline Pf (4.84 kg/plot) & & $0.25 \mathrm{a}$ & $25.25 \mathrm{a}$ & $0.27 \mathrm{~b}$ & $0.92 \mathrm{a}$ & $0.25 \mathrm{a}$ & $0.68 b$ & $0.67 \mathrm{a}$ & $0.81 b$ \\
\hline \multicolumn{10}{|l|}{ Fertilizer Types } \\
\hline Un manure & & $0.00 \mathrm{c}$ & $0.00 c$ & $0.00 c$ & $0.00 \mathrm{~b}$ & $0.00 \mathrm{c}$ & $0.57 c$ & $0.00 \mathrm{~b}$ & $0.00 \mathrm{c}$ \\
\hline Pf (4.84 kg/plot) & & $0.16 \mathrm{a}$ & $0.39 \mathrm{~b}$ & $16.09 \mathrm{a}$ & $0.53 \mathrm{a}$ & $0.16 \mathrm{a}$ & $0.67 b$ & $13.77 \mathrm{a}$ & $1.52 \mathrm{a}$ \\
\hline Pf (9.68 kg/plot) & & $0.09 \mathrm{~b}$ & $0.48 \mathrm{a}$ & $8.53 b$ & $0.57 \mathrm{a}$ & $0.09 \mathrm{~b}$ & $0.74 \mathrm{a}$ & $5.52 \mathrm{ab}$ & $0.77 \mathrm{~b}$ \\
\hline \multicolumn{10}{|l|}{ Crop Types } \\
\hline TVSu1166 & & $0.12 \mathrm{a}$ & $0.12 b$ & $11.65 \mathrm{a}$ & $0.66 \mathrm{a}$ & $0.12 \mathrm{a}$ & $0.67 \mathrm{a}$ & $11.99 a$ & $0.74 \mathrm{a}$ \\
\hline TVSu999 & & $0.05 b$ & $0.45 \mathrm{a}$ & $4.76 \mathrm{~b}$ & $0.08 b$ & $0.05 b$ & $0.65 a$ & $0.86 \mathrm{~b}$ & $0.78 \mathrm{a}$ \\
\hline
\end{tabular}

Table 10. Manuring effect on Bambara agronomic and physiological efficiency of $\mathrm{N}$ use.

\begin{tabular}{|c|c|c|c|c|c|c|c|c|c|c|c|}
\hline Treatm & lents & $\begin{array}{l}\text { Agronomic } \\
\text { Efficiency } \\
\text { (AE) }\end{array}$ & $\begin{array}{c}\text { Agronomic } \\
\text { N Use } \\
\text { Efficiency } \\
\text { (ANUE) }\end{array}$ & $\begin{array}{c}\text { Apparent } \\
\text { Recovery } \\
\text { Efficiency } \\
\text { (RE) }\end{array}$ & $\begin{array}{c}\text { Apparent } \\
\text { Recovery } \\
\text { Efficiency by } \\
\text { Difference \% }\end{array}$ & $\begin{array}{l}\text { Physiology } \\
\text { Efficiency } \\
\text { (PE) }\end{array}$ & $\begin{array}{l}\text { Fertilizer } \\
\text { Use } \\
\text { Efficiency } \\
\text { (FAE) }\end{array}$ & $\begin{array}{c}\mathrm{N} \\
\text { Removed } \\
\text { @ harvest }\end{array}$ & $\begin{array}{c}\text { Internal } \\
\text { Utilization } \\
\text { Efficiency } \\
\text { (IE) }\end{array}$ & $\begin{array}{l}\text { Utilization } \\
\text { Efficiency } \\
\text { (EU) }\end{array}$ & $\begin{array}{c}\text { Partial } \\
\text { Factor } \\
\text { Production } \\
\text { (PFP) }\end{array}$ \\
\hline Fertilizer & Crop & & & & & & & & & & \\
\hline Types & Types & & & & & & & & & & \\
\hline Un-manure & $\begin{array}{c}\text { Sole } \\
\text { Bambara }\end{array}$ & $0.00 \mathrm{~b}$ & $0.00 \mathrm{~b}$ & $0.00 c$ & $0.00 c$ & $0.00 \mathrm{~b}$ & $0.00 \mathrm{~b}$ & $0.00 \mathrm{a}$ & $304.80 \mathrm{~b}$ & $0.00 \mathrm{~b}$ & $0.00 c$ \\
\hline $\begin{array}{c}\text { Cocoa pod } \\
\text { husk }(\mathrm{CPH})\end{array}$ & & $3.19 \mathrm{~b}$ & $3.19 \mathrm{~b}$ & $318.7 b$ & $19.40 \mathrm{a}$ & $0.02 b$ & $0.71 b$ & $-1.68 b$ & $535.73 a$ & $318.7 \mathrm{~b}$ & $9.33 b$ \\
\hline N.P.K & & $12.55 \mathrm{a}$ & $12.55 \mathrm{a}$ & $1254.5 \mathrm{a}$ & $11.10 \mathrm{~b}$ & $1.06 \mathrm{a}$ & $3.01 \mathrm{a}$ & $-2.07 c$ & $540.23 a$ & $1254.5 \mathrm{a}$ & $38.84 a$ \\
\hline Un-manure & $\begin{array}{l}\text { Bambara } \\
+ \text { Sesame }\end{array}$ & $0.00 \mathrm{a}$ & $0.00 \mathrm{a}$ & $0.00 \mathrm{a}$ & $0.00 \mathrm{c}$ & $0.00 \mathrm{~b}$ & $0.00 \mathrm{~b}$ & $0.00 \mathrm{a}$ & $105.48 \mathrm{~b}$ & $0.00 \mathrm{a}$ & $0.00 \mathrm{c}$ \\
\hline $\begin{array}{c}\text { Cocoa pod } \\
\text { husk }(\mathrm{CPH})\end{array}$ & & $4.52 \mathrm{a}$ & $4.52 \mathrm{a}$ & $451.6 \mathrm{a}$ & $14.64 \mathrm{a}$ & $0.09 \mathrm{~b}$ & $1.42 \mathrm{a}$ & $-2.76 c$ & $218.38 \mathrm{a}$ & $90.32 \mathrm{a}$ & $13.32 \mathrm{~b}$ \\
\hline N.P.K & & $0.79 a$ & $0.79 a$ & $78.7 \mathrm{a}$ & $4.02 \mathrm{~b}$ & $0.29 \mathrm{a}$ & $0.30 \mathrm{~b}$ & $-0.49 b$ & $113.30 \mathrm{~b}$ & $15.75 a$ & $38.52 \mathrm{a}$ \\
\hline Lsd (0.05) & & 13.67 & 13.67 & 1367.2 & 2.17 & 0.15 & 1.08 & 0.16 & 40.80 & 273.43 & 6.19 \\
\hline \multicolumn{2}{|l|}{ Types } & & & & & & & & & & \\
\hline Un-manure & & $0.00 \mathrm{~b}$ & $0.00 \mathrm{~b}$ & $0.00 \mathrm{~b}$ & $0.00 \mathrm{c}$ & $0.00 \mathrm{~b}$ & $0.00 \mathrm{c}$ & $0.00 \mathrm{a}$ & $205.14 c$ & $0.00 \mathrm{~b}$ & $0.00 \mathrm{c}$ \\
\hline
\end{tabular}




\begin{tabular}{|c|c|c|c|c|c|c|c|c|c|c|}
\hline \multicolumn{11}{|l|}{ Continued } \\
\hline $\begin{array}{l}\text { Cocoa pod } \\
\text { husk }(\mathrm{CPH})\end{array}$ & $3.85 \mathrm{ab}$ & $3.85 \mathrm{ab}$ & $385.1 \mathrm{ab}$ & $17.03 a$ & $0.056 \mathrm{~b}$ & $1.06 \mathrm{a}$ & $-2.22 c$ & $377.06 a$ & $204.5 b$ & $11.324 \mathrm{~b}$ \\
\hline N.P.K & $6.67 \mathrm{a}$ & $6.67 \mathrm{a}$ & $666.6 a$ & $7.56 \mathrm{~b}$ & $0.24 \mathrm{~b}$ & $1.66 \mathrm{a}$ & $-1.28 \mathrm{~b}$ & $326.76 \mathrm{~b}$ & $635.1 \mathrm{a}$ & $38.68 \mathrm{a}$ \\
\hline \multicolumn{11}{|l|}{ Crop Types } \\
\hline $\begin{array}{c}\text { Sole } \\
\text { Bambara }\end{array}$ & $5.24 \mathrm{a}$ & $5.24 \mathrm{a}$ & $524.4 \mathrm{a}$ & 10.17 & $0.36 a$ & $1.24 \mathrm{a}$ & $-1.25 b$ & $460.25 a$ & $524.4 \mathrm{a}$ & $16.06 \mathrm{a}$ \\
\hline $\begin{array}{l}\text { Bambara } \\
+ \text { Sesame }\end{array}$ & $1.77 \mathrm{~b}$ & $1.77 \mathrm{a}$ & $176.8 \mathrm{a}$ & 6.22 & $0.13 b$ & $1.24 \mathrm{~b}$ & $-1.08 \mathrm{a}$ & $145.72 \mathrm{~b}$ & $35.4 \mathrm{~b}$ & $17.28 \mathrm{a}$ \\
\hline $\begin{array}{c}\text { Fertilizer } \\
\text { Types }\end{array}$ & 2.37 & 2.37 & 236.70 & 0.53 & 0.03 & 0.38 & 0.05 & 12.16 & 130.18 & 0.19 \\
\hline Crop Types & 2.15 & 2.15 & 215.10 & 0.57 & 0.07 & 0.43 & 0.07 & 35.99 & 172.49 & 0.58 \\
\hline
\end{tabular}

productivity (PFP) which were significant with $9.68 \mathrm{~kg}$ fertilizer treatments. Sesame variety (NCRIBen04E) and Bambara nut variety (TVSu1166) had enhanced Agronomy Efficiency (AE), N-removed at harvest and Internal Utilization Efficiency (IE) which was significantly enhanced by $9.68 \mathrm{~kg}$ pelletized fertilizer treatment. The influence of fertilizer type pronounced on the resource use efficiencies parameters measured in this study. The $4.84 \mathrm{~kg}$ treatment had higher partial factor productivity (PFP). Sesame variety E8 and Bambara nut variety (TVS U399) had higher N-removed at harvest at $9.68 \mathrm{~kg} / \mathrm{plot}$ organic fertilizer. For both Sesame and Bambara nut varieties, $9.68 \mathrm{~kg} / \mathrm{plot}$ enhanced most of the indicators of $\mathrm{N}$ use efficiency compared to the un-manure (control) and $4.84 \mathrm{~kg}$ fertilizer. Agronomy Efficiency (AE), Apparent Recovery Efficiency by difference (RE\%), Physiology Efficiency (PE), Utilization Efficiency (UE), N-removed at harvest and Internal Utilization Efficiency (IE) had significantly higher values for $9.68 \mathrm{~kg} / \mathrm{plot}$ compared to $4.84 \mathrm{~kg} /$ plot (Table 10). Sesame variety NCRIBen04E and Bambara nut (TVS U1166) were significantly different from E8 and TVS U399 varieties for AE, N-remove at harvest, IE and PFP. The earlier varieties had enhanced apparent Recovery Efficiency (RE), Apparent Recovery Efficiency by difference (RE\%), Physiology Efficiency (PE), Utilization Efficiency (UE), and Internal Utilization Efficient (IE) when compared to NCRI Ben 048.

The measured parameters of agronomic and physiological efficiencies, nutrient up-take and use for sole and intercrops of Sesame and Bambara were affected by manure application. NPK fertilizer significantly improved Sesame and Bambara nuts both as sole and intercrop in terms of Agronomic efficiency (AE), Agronomic N use efficiency (ANUE), apparent recovery efficiency (RE), Physiology efficiency (PE), fertilizer use efficiency (FUE), internal efficiency (IE), utilization efficiency (UE) and partial factor productivity (PFP). Alizadeh et al. [22] attributed high yield performance to improvements in efficient of resource use of bean monoculture compared to intercropping treatments. Nutrient $\mathrm{P}$ is reported to decrease species competition place on nutrient resources [8] (Agele et al., 2011). The results obtained for nutrient use efficiency showed that application of $\mathrm{CPH}$ manure and NPK fertilizer affected all nutrient use efficiency para- 
meters measured for sole Bambara apart from the N-removed at harvest which was not affected. In our study AE values was less than 1, however it has been reported that $\mathrm{AE}$ values may be lower than 5 since it is dependent upon soil, crop, nutrient rate of absorption and losses. Low $\mathrm{AE}$ indicate that $\mathrm{N}$ was not fully utilized or limiting nutrient absorption. Results showed that $\mathrm{AE}$ values were greater than 5. Similar results was obtained by Mengel et al. [23] which was attributed to nitrogen fixing ability of legumes

Results showed that Agronomy efficiency (AE), Recovery efficiency (RE), Recovery efficiency by difference (RE\%) and Utilization efficiency (UE) were higher in values for Sesame (NCRIBen04E, Ex-Sudan) under $9.68 \mathrm{~kg}$ pelletized fertilized treatments is an indication of high yield productivity. The Physiology efficiency (PE) and partial factor productivity (PFP) were significantly influence by $4.84 \mathrm{~kg}$ pelletized fertilizer. The results were consistent with those obtained by [5] [24] that soil nutrient availability increased and enhanced crop yields and NUE by fertilizer rates. The author concluded that differences in soil nutrient status are a major source of variation in yield and nutrient uptake and subsequently nutrient utilization efficiency of oil seed crops. Application of $9.68 \mathrm{~kg}$ POF produced highest nutrient $\mathrm{N}$-use efficiency values (REF). However, E8 Sesame variety shows differences in variation for resources use efficiency. While $4.84 \mathrm{~kg} /$ plot POF increased internal use efficiency (IE), $9.68 \mathrm{~kg}$ enhanced PFP. According to Thobatsi [24], intercrops which differ in rooting and nutrient uptake patterns result in efficient use of nutrients, especially nitrogen uptake. In this study Sesame nutrient uptake response to N.P.K fertilizer is improved. The result also show that the application of Cocoa pod husk $(\mathrm{CPH})$ manure and NPK fertilizer to the Cashew soil with Sesame intercropped, alternatively with Bambara affected nutrient up-take of leaves and seed, thus increased proper utilization of the nutrient available from the soil. The greatest mean valves were obtained in the intercrop of Sesame plant alongside with Bambara crops. Agele et al. [5] [8] $(2008,2011)$ improved NUE for crops under application of organic and inorganic ferrttlizers. The result of the un-manure treated Sole sesame plants shows that $\mathrm{N}$ and $\mathrm{P}$ nutrient composition was significantly influence in seed production. This behavior could be attributed to nutritional balance in the soil. The results contradict the findings of Havlin et al. [25] who reported that $\mathrm{P}$ absorption is greater in soils with little $\mathrm{P}$ adsorbed to mineral surfaces. The highest nitrogen harvest index values for seed and leaf of Sesame plants were obtained from the un-manure treated plants. The superiority of these may be attributed to more vigorous nutrient exploitation advantage or to the legume effect from Bambara plants. Agele et al. [8] observed that without the applications of fertilizers, yield and NHI responses will be small. In this study the use of $\mathrm{CPH}$ manure, NPK fertilizer and the control (Un-manure) treatments enhanced Bambara leaf and seed nutrient composition. This could be attributed to differences in nutrient inputs by the fertilizers, differences in nutrient demand by the crops, one being a nitrogen fixing plants. It is reported that nutrient availability depended on nutrient concentration in the soil and environment and release 
pattern in synchrony with the crop needs [26]. The highest leaf $\mathrm{N}$ up-take values were obtained for the un-manure. Sole Bambara plant, while NPK treated plants recorded the highest $\mathrm{P}$ and $\mathrm{K}$ leaves uptake. This indicates that physiologically, nutrients uptake depends on water availability in the soil and ease of nutrient release [27]. The Nitrogen harvest index of TVSu1199 Bambara variety was higher under the application of $9.68 \mathrm{~kg}$ pelletizer treatment compare to TVSu999 Bambara variety. This result was in line to the conclusion of Agele et al. [8] that the crop yields and nutrient availability were higher in plots farmyard manure (FYM), thereby increased yields and enhancing soil nutrients.

\section{Conclusion}

The initial soil analysis showed that the soils under Cashew were deficient in $\mathrm{N}$, $\mathrm{P}, \mathrm{K}, \mathrm{Ca}, \mathrm{Mg}$ and $\mathrm{Zn}$. However, deficiency of $\mathrm{N}$ and $\mathrm{P}$ was most serious. The fertilizers, NPK fertilizer, CPH and Pelletized organic improved soil fertility. Growth and development variables of Sesame and Bambara nut varieties differed significantly for sole and intercrop combinations. Following manure application, significant increases in soil organic matter were observed in soil after harvest of Bambara and Sesame. Application of NPK, CPH and Pelletized organic fertilizer enhanced the vigour of Bambara and Sesame. Moreover, NPK, CPH and Pelletized organic fertilizer enhanced number of pods and seeds per plant, and dry matter yield.

\section{Conflicts of Interest}

The authors declare no conflicts of interest regarding the publication of this paper.

\section{References}

[1] Baghour, M., Ruiz, J.M. and Romero, L. (2000) Metabolism and Efficiency in Nitrogen Utilization during Senescence in Pepper Plants in Response to Nitrogenous Fertilization. Journal of Plant Nutrition, 23, 91-101. https://doi.org/10.1080/01904160009382000

[2] Scholberg, J., McNeal, B., Boote, K.J. and Jones, J.W. (2000) Nitrogen Stress Effects on Growth and Nitrogen Accumulation by Field-Grown Tomato. Agronomy Journal, 92, 159-167. https://doi.org/10.2134/agronj2000.921159x

[3] Stoorvogel, J., Smaling, E. and Janssen, B.H. (1993) Calculating Soil Nutrient Balances in Africa at Different Scales. 1. Supra-National Scale. Fertilizer Research, 35, 227-235. https://doi.org/10.1007/BF00750641

[4] Moisier, A.R., Syers, J.K. and Freney, J.R. (2004) Agriculture and the Nitrogen Cycle: Assessing the Impacts of Fertilizer Use on Food Production and the Environment. The Scientific Committee on Problems of the Environment (SCOPE 65), of the International Council on Science, Island Press, London, 296.

[5] Agele, S.O., Adeniji, I.E., Alabi, I.A. and Olabomi, A. (2008) Responses of Growth, Yeild and N Use Efficiency of Selected Tomato Cultivars to Variations in the Hydrothermal Regimes of the Cropping Seasons in a Rainforest Zone of Nigeria. Journal of Plant Interactions, 2, 273-285. https://doi.org/10.1080/17429140802112863 
[6] Egbe, O.M., Kalu, B.A. and Idoga, S. (2009) Contribution of Common Food Legumes to the Fertility Status of Sandy Soils of the Moist Savanna Woodland of Nigeria. Report and Opinion Journal, 1, 45-62.

[7] Paul, G.C., Bokhtiar, S.M., Rashed, M.A. and Mannan, M.A. (2007) Integrated Nutrient Management for Sustainable Sugarcane Production in Different Agro-Ecological Zones of Bangladesh. Planter, 83, 529-538.

[8] Agele, S.O., Adeyemo, A.J. and Famuwagun, I.B. (2011) Effects of Agricultural Wastes and Mineral Fertilizer on Soil and Plant Nutrient Status, Growth and Yield of Tomato. Archives of Agronomy and Soil Science, 57 91-104. https://doi.org/10.1080/03650340903225040

[9] Mengel, K., Kirkby, C.A., Kosegarten, H. and Appel, T. (2006) Principles of Plant Nutrition. 5th Edition, Springer Publishers, New York, 849 p.

[10] Rather, K., Schenk, M.K., Everaarts, A.P. and Vethmu, S. (1999) Response of Yield and Quality of Cauliflower Varieties (Brassica oleracea) to Nitrogen Supply. Journal of Horticultural Science and Biotechnology, 74, 658-664. https://doi.org/10.1080/14620316.1999.11511169

[11] Pavlovic, R., Stevanovic, D. and Kresovic, M. (1996) Effect of Growing Method and Lettuce Fertilization on Nitrate Content in Leaf. Acta Horticulturae, 443, 885-890.

[12] Akintoye, A.H., Kling, J.G. and Lucas, E.O. (1993) Nitrogen Use Efficiency of Single, Double and Synthetic Maize Lines Grown at Four N Levels in Three Ecological Zones of West Africa. Field Crops Research, 27, 60-67.

[13] Lafitte, H.R. and Edmeades, G.O. (1994) Improvement for Tolerance to Low Soil Nitrogen in Tropical Maize II. Grain Yield, Biomass Production and N Accumulation. Field Crops Research, 39, 15-25. https://doi.org/10.1016/0378-4290(94)90067-1

[14] Cassman, K.G., Peng, S., Olk, D.C., Ladha, J.K., Reichardt, W., Dobermann, A. and Singh, U. (1998) Opportunities for Increasing Nitrogen Use Efficiency from Improved Resource Management in Irrigated Rice Systems. Field Crops Research, 56, 7-38.

[15] McCall, D. and Willumsen, J. (1998) Effects of Nitrate, Ammonium and Chloride Application on the Yield and Nitrate Content of Soil Grown Lettuce. Journal of Horticultural Science and Biotechnology, 72, 698-703. https://doi.org/10.1080/14620316.1998.11511036

[16] Vanlauwe, B., Bationo, A., Chianu, J., Giller, K.E., Merckx, R., Mokwunye, U., Ohiokpehai, O., Pypers, P., Tabo, R., Shepherd, K.D., Smaling, E.M.A., Woomer, P.L. and Sanginga, N. (2010) Integrated Soil Fertility Management: Operational Definition and Consequences for Implementation and Dissemination. Outlook on Agriculture, 39, 17-24. https://doi.org/10.5367/000000010791169998

[17] Vanlauwe, B., Kihara, J., Chivenge, P., Pypers, P., Coe, R. and Six, J. (2011) Agronomic Use Varieties of Groundnut as Influenced by Sowing Dates. Journal of SAT Agricultural Varieties Research on Crops, 6, 173-174.

[18] Dobermann, A. (2007) Nutrient Use Efficiency: Measurement and Management. IFA International Workshop on Fertilizer Best Management Practices, Brussels, $1-28$.

[19] Odo, P.E. (1991) Evaluating Short and Tall Sorghum Varieties in Mixtures with Cowpea in Sudan Savanna of Nigeria: LER, Grain Yield and System Productivity Index. Experimental Agriculture, 27, 435-441. https://doi.org/10.1017/S0014479700019426 
[20] De Wit, C.T. and Van den Bergh, J.P. (1965) Competition between Herbage Plants. Netherlands Journal of Agricultural Science, 13, 212-221.

[21] Fageria, N.K., Slaton, N.A. and Baligar, V.C. (2003) Nutrient Management for Improving Lowland Rice Productivity and Sustainability. Advances in Agronomy, 80, 63-152. https://doi.org/10.1016/S0065-2113(03)80003-2

[22] Alizadeh, Y., Koocheki, A. and Nassiri-Mahallati, M. (2010) Yield, Yield Components and Potential Weed Control of Intercropping Bean (Phaseolus vulgaris L.) with Sweet Basil (Ocimum basilicum L.). Iranian Journal of Field Crops Research, 7, 541-553.

[23] Tsubo, M., Walker, S. and Ogindo, H.O. (2005) A Simulation Model of Cereal-Legume Intercropping Systems for Semi-Arid Regions: I. Model Development. Field Crops Research, 93, 10-22. https://doi.org/10.1016/j.fcr.2004.09.002

[24] Yusuf, A.A., Iwuafor, E.N.O., Abaidoo, R.C., Olufajo, O.O. and Sanginga, N. (2009) Effect of Crop Rotation and Nitrogen Fertilization on Yield and Nitrogen Efficiency in Maize in the Northern Guinea Savanna of Nigeria. African Journal of Agricultural Research, 4, 913-921.

[25] Havlin, J.L., Beaton, J.D., Tisdale, S.L. and Nelson, W.L. (2005) Soil Fertility and Fertilizers: An Introduction to Nutrient Management. Pearson Prentice Hall, Upper Saddle River.

[26] Shehu, H.E., Kwari, J.D. and Sandabe, M.K. (2010) Effects of N, P, K Fertilizers on Yield, Content and Uptake of N, P and K by Sesame (Sesamun indicum). International Journal of Agriculture and Biology, 12, 845-850.

[27] Trenbath, B.R. (1976) Plant Interactions in Mixed Crop Communities. In: Papendick, R.I., Sanchez, P.A. and Triplett, G.B., Eds., Multiple Cropping, American Society of Agronomy Special Publication, No. 22. 